The following pages constitute the final, accepted and revised manuscript of the article:

Hallmann, Rupert and Horn, Nathalie and Selg, Manuel and Wendler, Olaf and Pausch, Friederike and Sorokin, Lydia M

"Expression and function of laminins in the embryonic and mature vasculature."

Physiol Rev. 2005 Jul;85(3):979-1000.

Publisher: American Physiological Society

Use of alternative location to go to the published version of the article requires journal subscription.

Alternative location: http://dx.doi.org/10.1152/physrev.00014.2004 


\title{
Expression and Function of Laminins in the Embryonic and Mature Vasculature
}

\author{
Rupert Hallmann, Nathalie Horn§, Manuel Selg, Olaf Wendler§, \\ Friederike Pausch $\S$ and Lydia M. Sorokin \\ Experimental Pathology, Lund University, Sweden; §Interdisciplinary Center for Clinical \\ Research (IZKF), University of Erlangen, Erlangen, Germany.
}

Author for correspondence:
Lydia Sorokin
Experimental Pathology
Lund University
Se-22185 Lund, Sweden
Tel +4646173400
Fax +4646158202
Email: Lydia.Sorokin@pat.lu.se 


\section{Table of Contents}

1. Overview of Endothelial Cell Development, Differentiation and Maturation

2. Expression of Endothelial Cell-Specific Extracellular Matrix Molecules During Endothelial Cell Development/Maturation

Basement membranes in general

Laminins

3. Differential Expression of Laminin Receptors on Developing and Mature Endothelium Integrins

Lutheran blood group glycoptrotein

Dystroglycan

Syndecans

4. Function of Laminin-Endothelial Cell Interactions

Vessel Formation

Vessel Stability

Barrier Function

5. The Role of Other Extracellular Matrix Molecules in Blood Vessel Development 


\begin{abstract}
Endothelial cells of the blood and lymphatic vasculature are polarized cells with luminal surfaces specialized to interact with inflammatory cells upon the appropriate stimulation; they contain specialized trans-cellular transport systems, and their basal surfaces are attached to an extracellular basement membrane. In adult tissues the basement membrane forms a continuous sleeve around the endothelial tubes and the interaction of endothelial cells with basement membrane components plays an important role in the maintenance of vessel wall integrity. During development, the basement membrane of endothelium provides distinct spatial and molecular information which influences endothelial cell proliferation, migration and differentiation/ maturation. Microvascular endothelium matures into phenotypically distinct types: continuous, fenestrated and discontinuous, which also differ in their permeability properties. Development of these morphological and physiological differences are thought to be controlled by both soluble factors in the organ or tissue environment, and by cell-cell and cellmatrix interactions.
\end{abstract}

Basement membranes of endothelium, like those of other tissues, are composed of laminins, type IV collagens, heparan sulphate proteoglycans and nidogens. However, isoforms of all four classes of molecules exist, which combine to form structurally and functionally distinct basement membranes. The endothelial cell basement membranes have been shown to be unique with respect to their laminin isoform composition. Laminins are a family of glycoprotein heterotrimers composed of an $\alpha, \beta$ and $\gamma$ chain. To date $5 \alpha, 4 \beta$ and $3 \gamma$ laminin chains have been identified that can combine to form 15 different isoforms. The laminin $\alpha$ chains are considered to be the functionally important portion of the heterotrimers, as they exhibit tissue-specific distribution patterns and contain the major cell interaction sites. Vascular endothelium expresses only two laminin isoforms and their expression varies depending on the developmental stage, vessel type and the activation state of the endothelium. Laminin 8 (composed of laminin $\alpha 4, \beta 1, \gamma 1$ chains) is expressed by all endothelial cells regardless of their stage of development and its expression is strongly upregulated by cytokines and growth factors that play a role in inflammatory events. Laminin 10 (composed of laminin $\alpha 5, \beta 1, \gamma 1$ chains) is detectable primarily in endothelial cell basement membranes of capillaries and venules commencing 3-4 weeks after birth. In contrast to laminin 8 , endothelial cell expression of laminin 10 is upregulated only by strong 
proinflammatory signals and, in addition, angiostatic agents such as progesterone. Other extracellular matrix molecules, such as BM40 (also known as SPARC/osteonectin), thrombospondin 1 and 2, fibronectin, nidogen 1 and 2, and collagen types VIII, XV and XVIII, are also differentially expressed by endothelium, varying with the endothelium type and/or pathophysiological state. The data argue for a dynamic endothelial cell extracellular matrix that presents different molecular information depending on the type of endothelium and/or physiological situation. This review will outline the unique structural and functional features of vascular basement membranes, with focus on the endothelium and the laminin family of glycoproteins.

\section{Overview of Endothelial Cell Development, Differentiation and Maturation}

Endothelial cell development occurs in several distinct steps, commencing with the formation of simple endothelial tubes via processes of vasculogenesis and angiogenesis, followed by the recruitment of mural cells and differentiation into different vessel types (e.g. capillary, venous and arterial) and, finally, tissue- or organ-specific maturation of capillaries and post-capillary venules. Tube formation has received considerable attention and several excellent reviews exist on this topic $(23,29,79,144)$. While factors have been identified that control differentiation of venous versus arterial endothelium, tissue- and organ-specific factors involved in vessel maturation remain less well studied. However, it is clear that the local environment plays a significant role in defining barrier function or permeability of endothelium, the complexity of junctional complexes, apical and basal surface specialization, as well as the supramolecular organization of the basement membrane (Fig. 1).

The nascent vascular network in the embryo arises principally by vasculogenesis, i.e. de novo vessel formation from angioblasts or stem cells, and by sprouting angiogenesis, i.e. sprouting and branching of a pre-existing endothelial sheet (141). In addition, there is evidence for nonsprouting angiogenesis or intussusception (splitting of preexisting_vessels) as a mode of rapidly expanding vascular networks, without the need for endothelial cell proliferation (reviewed in (21)). 
Signaling via vascular endothelial growth factor (VEGF) (99), originally know as vascular permeability factor (VPF) (155) because of its ability to form edema, is important for several aspects of vessel formation $(39,44,45,119)$. A number of VEGFs have been identified to date and their interactions with different VEGF-receptors have been partially unraveled (45). Since most information is available for the role of VEGF-A and its receptor VEGFR2 (also known as flk-1) we describe only this interaction here and its function on initiation of vessel formation and the series of molecular and cellular events that lead to vessel maturation $(24,25,144,200)$. $\mathrm{CD} 31^{+} / \mathrm{CD} 34^{+} / \mathrm{VEGFR} 2$ positive angioblasts form a vascular plexus that gives rise to the yolk sac arteries and veins and, within the embryo, to the dorsal aorta and the cardinal vein (41, $46,126,195)$. Sprouting of this primary vasculature by angiogenesis results in extension of the vascular tree and is associated with the upregulation of genes involved in vessel branching and maturation, including angiopoietin-2 (Ang-2), nitric oxide (NO) synthase and VEGF-A $(23,200)$. The current model of vascular sprouting hypothesizes that the vessels dilate in response to nitric oxide (NO), a product of NO synthase, and become leaky due to the action of VEGF (79). Activation of proteases, such as matrix metalloproteinases (MMPs) and suppression of protease inhibitors (tissue inhibitor of matrix metalloproteinases- TIMPs), results in proteolytic processing of the underlying basement membrane and surrounding interstitial matrix $(79,82)$. Plasma proteins, such as fibrinogen and fibronectin, leak from the nascent vessels and provide a "provisional matrix" for migration of endothelial cells to form a new sprout. The endothelial cells migrate via specific interactions with the provisional matrix and respond to the chemotactic and mitogenic effects of VEGF and other growth factors (Fig. 1) $(29,79)$.

The nascent vessels are subsequently stabilized by the recruitment of pericytes and smooth muscle cells, and the associated formation of stable basement membranes. Several factors have been identified that are essential for recruitment of mural cells, including a) platelet derived growth factor $\mathrm{B}$ (PDGF-B) and its receptor, PDGFR $\beta\{$ o. $1999 \# 692\} ;$ b) sphingosine-1-phosphate-1 (S1P-1) and endothelial differentiation sphingolipid-G-proteincoupled receptor-1 (EDG-1) (87); c) angiopoietins and Tie1 and Tie2 receptor tyrosine kinases (104) and d) transforming growth factor- $\beta$ (TGF $\beta$ ) and associated receptors RI, RII and endoglin $(62,132)$. PDGF-B, PDGFR $\beta$ and EDG-1 null mice all lack recruitment of pericytes $(65,103)$, resulting in vessel instability and perinatal death. Both PDGFR $\beta$ and EDG-1 are expressed on 
pericytes and while PDGFR $\beta$ is responsible for the pericyte response to the chemotactic and mitogenic signals of PDGF-B released from endothelial cells. The role of S1P-1-EDG1 interactions are less well defined. It is hypothesized that EDG-1 signaling occurs downstream of PDGF and may be involved in extracellular matrix production (74).

The Tie1 and Tie2 receptor tyrosine kinases, and the two Tie2 ligands, Ang1 and Ang2, produced by endothelial cells and pericytes, respectively, and possibly also the recently described Ang3 and Ang4, are also critical for vessel stability and for vessel sprouting (104, 189). Ang1 makes the nascent vessels leak-resistent probably by facilitating interactions between endothelium and mural cells, while Ang2 acts as an antagonist of Ang1 in the absence of VEGF and destabilizes vessels, leading to their regression, and promotes sprouting in the presence of VEGF $(104,105$, $167,173,200)$.

TGF- $\beta 1$ is a multifunctional cytokine that promotes maturation of vessels by stimulating the production of extracellular matrix and inducing conversion of mesenchymal cells to mural cells $(26,132)$. Its effects can be both pro- and anti-angiogenic, depending on the signal cascades induced (62). Elimination of the TGF- $\beta 1$ binding protein, endoglin, results in normal vasculogenesis but mice die during embryogenesis as a result of defective vascular remodeling and smooth muscle differentiation. Mutations in endoglin in man results in Telangietasia type 1, characterized by arterial-venous malformations and hemorrhages (130). The data suggest that TGF- $\beta 1 /$ endoglin induced ALK1 signaling results in endothelial cell and fibroblast proliferation and migration and are pro-angiogenic, while TGF- $\beta 1$ induced ALK5 signaling induces plasminogen activator inhibitor (PAI-1) in endothelial cells, which promotes vessel maturation by preventing degradation of the provisional matrix around nascent vessels. The ratio of TGF- $\beta 1$ induced ALK1 versus ALK5 signaling determines the pro- or anti-angiogenic effects of TFG- $\beta$ $(62,63)$.

The final or optimal pattern of the vascular network for an organ is determined by branching, remodeling, and pruning of its different segments. Some signaling pathways involved in regulating branching in the embryo have been identified (ephrins, VEGF-A, neuropilins). For example, the transmembrane molecule ephrin-B2 is highly expressed on precursors of arterial 
endothelium during embryogenesis, while Eph-B4, a tyrosine receptor kinase that binds ephrinB2, is found at much higher levels on developing veins than arteries. Bidirectional ephrin-B2 and Eph-B4 receptor signaling repels the arterial and venous sides of the developing vasculature and, thereby, guides branching $(3,192,193)$. It has been recently shown that presentation of VEGF-A by heparin (or heparan sulfate proteoglycans) as opposed to soluble VEGF-A, results in enhanced vessel branching (146). In addition, studies involving zebrafish embryos suggest that VEGF-A signaling through Notch determines arterial endothelium (96). Arterial growth is then promoted by binding of a specific VEGF-A isoform, VEGF $_{164}$ (a heparin-binding form), to VEGFR2 and neuropilin signaling (120).

Organ- or tissue-specific maturation of capillary endothelium into continuous (most blood vessels), continuous with complex tight junctions (brain, retina \& testis), discontinuous (liver \& spleen), diaphragmed fenestrated (peri-tubular capillaries in kidney/endocrine glands) or nondiaphragmed fenestrated endothelium (glomerulus) $(140,142,165)$, remains the least understood step in vessel formation. It is an aspect of vessel development that is likely to be regulated by local mediators, including both soluble factors, cell-cell and cell-matrix interactions. Heterotypic transplantation studies have shown that brain blood vessels growing into grafts of peripheral tissues acquire peripheral vascular morphology with fewer tight junction, whereas peripheral vessels growing out of grafts into brain tissue assume tight junctions characteristic of brain vessels $(5,29,166)$. Further, tissue-specific vascular growth factors have recently been described, such as endocrine gland VEGF (EG-VEGF) also known as prokineticin 1 (101), and prokineticin 2 also known as Bv8, which are structurally distinct from the VEGF-family $(9,97,106)$ and interact with a class of G-protein-coupled receptors (101). prokineticin 1 and 2 have been implicated in a range of physiological functions including migration, proliferation and fenestration of endothelial cells in vitro (9). The identification of such tissue-specific vascular growth factor(s) suggests the possible existence of additional tissue-specific factors that may complement the VEGF system to achieve specific, local maturation of blood vessel endothelium and also of perivascular cells (22). Alternatively, combinations of different known growth factors and their splice variants may result in a specific local cytokine signal pattern that induces local maturation of the vasculature (145). 
Extracellular matrix molecules of vascular basement membranes and the subjacent interstitial matrix also provide cues for regulating proliferation, survival, migration and differentiation of both endothelial cells and mural cells, and have been implicated in several steps of vessel formation. These effects can be both direct and indirect as the extracellular matrix can accumulate, retain and present growth factors (such as VEGF and FGF-2) and proenzymes (proforms/inactive of the MMPs) involved in vessel development. In addition, cleavage products of extracellular matrix molecules can act as pro- or anti-angiogenic factors (e.g. laminin $\alpha 4$ G4-5, endostatin, restin). However, the role of extracellular matrix molecules in blood vessel formation remains relatively poorly studied and it is only recently that the unique and dynamic nature of the endothelial cell basement membrane has become apparent.

\section{Expression of Endothelial Cell-Specific Extracellular Matrix Molecules During Endothelial Cell Development/Maturation}

\section{Basement membranes in general}

Basement membranes are a highly specialized extracellular matrix that in blood vessels underlie endothelial cells, encasing associated pericytes, but also surround individual smooth muscle cells in veins and arteries. They are thin protein sheets (50 $\mathrm{nm}$ in thickness), the major components of which are the laminins, collagen type IV, nidogens and the heparan sulphate proteoglycan, perlecan. In addition, there are several minor components that in endothelial basement membranes include BM40 (also known as osteonectin and SPARC), fibulin 1 (or BM90) and 2, collagen types VIII, XV, XVIII, and thrombospondin 1 and 2 (176).

The basic framework of the basement membrane is thought to be created by two independent and distinct networks of type IV collagen and laminin. In vitro, it has been shown that type IV collagen and laminin self-assemble into a three-dimensional network independently of each other $(204,206)$. Recombinant nidogen-1 has been shown to bridge the two networks by binding to both collagen type IV and laminin in vitro (47), and in addition interacts with the heparan sulphate proteoglycan, perlecan, which in turn binds to the C-terminal portion of the laminin and to type IV collagen, thereby stabilizing the basement membrane network (175). In addition, 
fibulins have been shown to bind strongly to laminins and nidogens, but also to several proteoglycans and fibronectin $(152,180)$. They may, therefore, contribute to crosslinking of basement membrane components and to the interaction of the basement membrane with the underlying interstitial matrix of the stroma. Recent data from nidogen knockout mice $(113,118$, 154) suggest that this is a highly schematic and simplified concept of basement membrane assembly and that variations on this theme occur in vivo. Figure 2 illustrates a model for interactions between the major basement membrane components.

While the basic building blocks of basement membranes are similar, a considerable degree of complexity exists with variability in not only the relative amounts of components, but also the presence of site-specific isoforms and other unique components. It is now known that isoforms of type IV collagen (71), laminins $(33,100,112,186)$, heparan sulphate proteoglycans $(12,77)$ and even nidogen (88) exist, which have distinct temporal and spatial distribution patterns, resulting in basement membranes that are not only structurally but also functionally distinct (Table 1). Furthermore, these variations in basement membrane composition have significant consequences on how basement membranes interact with cellular ligands or are anchored to the surrounding interstitial matrix of the stroma.

Table 1 Major Basement Membrane Components and their Principal Sites of Localization

\begin{tabular}{|l|l|l|}
\hline Component & Composition & Major Site/s of Expression \\
\hline Laminin 1 & $\alpha 1 \beta 1 \gamma 1$ & developing epithelia \\
\hline Laminin 2 & $\alpha 2 \beta 1 \gamma 1$ & all myogenic tissues, peripheral nerves \\
\hline Laminin 3 & $\alpha 1 \beta 2 \gamma 1$ & myotendinous junction \\
\hline Laminin 4 & $\alpha 2 \beta 2 \gamma 1$ & $\begin{array}{l}\text { neuromuscular junction, mesangial matrix of } \\
\text { glomerulus }\end{array}$ \\
\hline Laminin 5 & $\alpha 3 \beta 3 \gamma 2$ & epidermis \\
\hline Laminin 6 & $\alpha 3 \beta 1 \gamma 1$ & epidermis \\
\hline Laminin 7 & $\alpha 3 \beta 2 \gamma 1$ & epidermis \\
\hline Laminin 8 & $\alpha 4 \beta 1 \gamma 1$ & $\begin{array}{l}\text { endothelium, smooth muscle, adipose tissue, } \\
\text { peripheral nerves }\end{array}$ \\
\hline Laminin 9 & $\alpha 4 \beta 2 \gamma 1$ & $\begin{array}{l}\text { endothelium, smooth muscle, neuromuscular } \\
\text { junction, mesangial matrix of glomerulus }\end{array}$ \\
\hline Laminin 10 & $\alpha 5 \beta 1 \gamma 1$ & $\begin{array}{l}\text { mature epithelium, mature endothelium, } \\
\text { smooth muscle }\end{array}$ \\
\hline Laminin 11 & $\alpha 5 \beta 2 \gamma 1$ & $\begin{array}{l}\text { mature epithelium, mature endothelium, smooth } \\
\text { muscle, neuromuscular junction, } \\
\text { glomerular basement membrane }\end{array}$ \\
\hline *Laminin 12 & $\alpha 2 \beta 1 \gamma 3$ & surface of ciliated epithelia \\
\hline Laminin 13 & $\alpha 3 \beta 2 \gamma 3$ & central nervous system/ retina \\
\hline
\end{tabular}




\begin{tabular}{|l|l|l|}
\hline Laminin 14 & $\alpha 4 \beta 2 \gamma 3$ & central nervous system/ retina \\
\hline Laminin 15 & $\alpha 5 \beta 2 \gamma 3$ & central nervous system/ retina \\
\hline Collagen IV & {$[\alpha 1(\mathrm{IV}) 2 \alpha 2(\mathrm{IV})]$} & most embryonic \& mature tissues \\
\cline { 2 - 3 } & {$[\alpha 3(\mathrm{IV}), \alpha 4(\mathrm{IV}), \alpha 5(\mathrm{IV})]$} & glomerular basement membrane \\
\cline { 2 - 3 } & {$[\alpha 5(\mathrm{IV}) 2 \alpha 6(\mathrm{IV})]$} & $\begin{array}{l}\text { skin, oesophagus, Bowman's capsule, smooth } \\
\text { muscle }\end{array}$ \\
\hline $\begin{array}{l}\text { Heparan sulfate } \\
\text { proteoglycans }\end{array}$ & perlecan & widespread in most BMs \\
\cline { 2 - 3 } Nidogen 1 & & widespread in most BMs \\
\hline Nidogen 2 & widespread in most BMs \\
\hline
\end{tabular}

* the existence of this isoform is controversial; BMs refers to basement membranes.

One function of basement membranes is to provide structural support for cells and to separate tissue compartments. More importantly, the individual components of basement membranes are dynamic in their interactions with cells and provide distinct spatial and molecular information that influence cell proliferation, migration and differentiation. The highly glycosylated nature of basement membrane components and the ability of molecules like heparan sulphate proteoglycans to interact with heparin domains render basement membranes high affinity and high capacity binders of growth factors, like VEGF and FGF-2 (125). In endothelium, the basement membrane is further likely to contribute to the barrier function (to both soluble molecules and migrating cells); to interactions with mural cells and thereby vessel stability; and to the transduction of mechanosensing signals from the lumen of the vessel to the vessel wall.

Basement membrane components are typically large oligomeric molecules that assemble to form supramolecular networks. Because of their functions, the proteins have low solubilities and show a tendency to aggregate. These characteristics have made them difficult to handle with traditional biochemical methods and have impeded studies on the structure and function of the specific isoforms of basement membrane components. However, modern techniques of nucleic acid analysis and manipulation, and of production of recombinant protein modules and fragments now provide possibilities for such studies. Data from structure-function studies as well as analysis of genetically manipulated mice and genetic diseases suggest that collagen type IV confers structural stability to the basement membrane, while the heparan sulphate proteoglycans act principally to crosslink the collagen type IV and laminin networks, bind soluble factors such as growth factors, and are important for the filtration properties of basement membranes. By 
contrast, laminins are the major biologically active components of basement membranes, with different isoforms conveying different signals in different tissues.

\section{Laminins}

The laminins are approximately cross-shaped heterotrimeric glycoproteins, composed of an $\alpha, \beta$ and $\gamma$ chain (Fig. 3). To date 5 distinct $\alpha, 4 \beta$ and $3 \gamma$ laminin chains have been identified that can combine to form 15 different isoforms (Table 1) $(30,149,177,186)$. While the existence of the majority of these laminins chains have been confirmed at both the gene and protein levels, there is little evidence to date for the existence of laminin $\beta 4$ protein.

A major achievement in basement membrane research over the last 15 years has been the accumulation of a wealth of protein and cDNA sequence data, which has revealed that all components of basement membranes are multidomain and multifunctional proteins bearing distinct, independently active domains that mediate interactions with cells, other extracellular matrix molecules or growth factors $(35,68)$. These studies have revealed conservation of distinct structural entities both within and between different groups of extracellular matrix molecules, hence, defining distinct "domains". Laminin $\alpha, \beta$ and $\gamma$ chains share homologous structures which include globular domains (domains IV and VI), rod-like domains containing EGF-like repeats known as laminin-like EGF or LE repeats (domains III and V), and domains forming the $\alpha$ helical coiled-coil of the long arm of the molecule (domains I and II) (Fig. 3). In addition, all laminin $\alpha$ chains identified to date contain a large C-terminal globular $(G)$ domain with five internal repeat motifs (known LG domains) (Fig. 3) (10, 181, 186). Important for the current review, is the fact that domains IV and VI, which comprise N-terminal portions of all chains and constitute the "short arms" of most laminins, are essential for self-assembly and, therefore, incorporation into the basement membrane, while the major cell binding domains are located in the C-terminal G domain of the $\alpha$ chains (Fig. 3).

The laminin $\alpha$-chains are considered the functionally active portion of the heterotrimers as they carry the major domains that interact with the cellular receptors. Further, their tissue-specific distribution patterns siggests that different laminin isoforms have different functions in different tissues (Table 1). This has been confirmed by genetic inactivation of laminin $\alpha$ chains and the 
analysis of genetic diseases: For example, elimination or mutation of laminin $\alpha 2$ in mouse and man results in a congenital muscular dystrophy $(7,114,115,198)$, elimination or mutation of laminin $\alpha 3$ lead to junctional epidermolysis bullosa, a severe skin blistering disease $(28,86,147$, 188,191 ), elimination of laminin $\alpha 4$ results in an embryonic blood vessel defect (174) (discussed in detail below), and elimination of laminin $\alpha 5$ results in multiple defects and late gestational lethality due to placental defects (109).

Vascular endothelium expresses two laminin $\alpha$ chains, depending on the endothelial cell type and state of growth or activation (Figs. $3 \& 4)(49,75,161,162)$. Laminin $\alpha 4$ is expressed by all endothelial cells regardless of their stage of development (Fig. 4), while laminin $\alpha 5$ is detectable primarily in basement membranes of capillaries and some venules commencing 3-4 weeks after birth (Fig. 4). Both laminin $\alpha 4$ and $\alpha 5$ chains can combine with laminin $\beta 1$ and $\gamma 1$ chains in endothelial cell basement membranes to form laminins 8 and 10, respectively (Fig. 3, Table 1). In situ hybridization studies have shown that laminin $\alpha 5$ is expressed by endothelial cells (161); in addition unpublished data from our laboratory suggest that pericytes also contribute laminin $\alpha 5$ to the endothelial basement membrane. Laminin $\alpha 5$ is not expressed by aortic endothelium, as revealed by the isolation of laminin $\alpha 4$ containing isoforms only from bovine aortic endothelial cells and by in situ hybridization studies, but rather by the surrounding smooth muscle cells (161, 162). Laminin $\alpha 5$ is also absent from the basement membranes underlying fenestrated endothelium of some glands and of the peritubular capillaries in the kidney, suggesting a correlation between absence of laminin $\alpha 5$ and fenestration formation.

In vitro studies using several endothelial cell lines and primary endothelial cells have shown that laminin $\alpha 4$ expression is strongly upregulated by cytokines and growth factors that play a role in inflammatory events $(49,159,183)$. By contrast, endothelial cell expression of laminin $\alpha 5$ is upregulated only by strong proinflammatory signals (such as TNF $\alpha$ ) and angiostatic agents, such as progesterone, that are considered necessary for maintenance of the endothelial cell phenotype $(159,183)$ (Fig. 4). 
Why different vessels express different laminins and why they are differentially regulated in endothelial cells is unknown, but suggests functional distinction. Mice lacking laminin $\alpha 4$ or laminin $\alpha 5$ have been generated and while laminin $\alpha 4$ null mice exhibit a blood vessel phenotype (described below) (174), laminin $\alpha 5$ null mice die during embryogenesis before this laminin chain is detectable in endothelial cell basement membranes $(109,183)$. Mice lacking laminin $\alpha 5$ alone or laminin $\alpha 4$ and $\alpha 5$ chains specifically in endothelial cell basement membranes are currently being generated in our laboratory and will aid in deciphering their potential functions. However, the temporal expression patterns and the structural characteristics of the laminin $\alpha$ and $\alpha$ chains, provide some clues to possible functions. Only laminin $\alpha 4$ is expressed in the developing endothelium from early stages of embryonic development (E8.5) (49), while laminin a5 occurs in endothelial cell basement membranes of mature vessels, predominantly in capillaries (161). This excludes the possibility that laminin $\alpha 5$ could have a role in the early stages of vessel development, but rather that it may be associated with maturation of the endothelium or its tissue /organ-specific characteristics.

Laminin $\alpha 4$ is also unusual among the laminins in lacking almost all N-terminal domains, including domains VI, V, IVa, IVb and IIIb $(49,75,186)$ (Fig. 3). The N-terminal domains of laminin $\alpha, \beta$ and $\gamma$ chains, which comprise three short arms of most laminins, have been shown to be important for laminin self-assembly $(178,204)$. Further, early studies on the globular domains within these short arms hypothesized a role in cross-linking the laminin network to the collagen type IV network (178). Although the latter has not been confirmed, it is possible that the ability of laminin $\alpha 4$ containing isoforms to both self-assemble and to be incorporated into the basement membrane may be compromised, due to the N-terminal truncation of the laminin $\alpha 4$ chain, resulting in a "looser" network that may be easier to penetrate by migrating lymphocytes or tumour cells (see below). In contrast, laminin $\alpha 5$ has an exceptionally long $\mathrm{N}$-terminus, due to the presence of a larger than usual IVb domain, and additional EGF repeats in domains V, IIIb and IIIa (Fig. 3) $(110,186)$. Further, laminin $\alpha 5$ is the only laminin $\alpha$ chain that carries exposed arginine-glutamine-aspartic acid (RGD)-cell binding sites in the $\mathrm{N}$-terminal portion of the chain. Although such RGD sequences occur in other laminins, they are normally exposed only after proteolytic cleavage and do not represent major cell binding sites. Two RGD binding sites occur 
in domain IVa and adjacent EGF-like repeats of the mouse laminin $\alpha 5$ chain, which support integrin $\alpha v \beta 3$, $\alpha v \beta 5$ and $\alpha 5 \beta 1$ mediated binding of endothelial cells, as well as binding of several other cell types (153). Integrins of the $\alpha \mathrm{v}$ series have been recently proposed to be negative regulators of angiogenesis and to be required for the stabilization of vessels upon maturation (72). In view of the exclusive expression of laminin $\alpha 5$ in quiescent, mature vessels, it cannot be excluded that some of the $\alpha v$ integrin effects are mediated by interactions with laminin $\alpha 5$ in the endothelial basement membrane.

\section{Differential Expression of Laminin Receptors on Developing and Mature Endothelium}

\section{Integrins}

Endothelial cells are anchored to their basement membrane by several receptor types, the principal ones being $\beta 1$ and $\beta 3$ integrins (Fig. 5). Integrins $\alpha 6 \beta 1$ and $\alpha 3 \beta 1$ are the major laminin $\alpha 4$ and $\alpha 5$-binding integrins that have been reported to be expressed by both developing and mature endothelial cells (Fig. 6) $(34,50,51,90)$. Integrins $\alpha v \beta 1, \alpha v \beta 3, \alpha v \beta 5$ and $\alpha 5 \beta 1$ are also highly expressed on endothelium and have been implicated in RGD-mediated binding to domain IVa of laminin $\alpha 5$ (Fig. 6) (153), in addition to fibronectin and, in the case of the $\alpha \mathrm{v}$ integrins, also to vitronectin, osteopontin, thrombospondin 1 and tenascin-C (190). Interestingly, integrin $\alpha 6 \beta 4$, which is best known as a receptor for laminin 5 (composed of $\alpha 3 \beta 3 \gamma 2$ chains, see Table 1) and is the major component of hemidesmosomes in the skin $(91,121,160)$, can also bind to laminin $\alpha 5$ (84) and has been reported to occur on the growing tips of sprouting blood vessels $(36,55,76)$. However, laminin $\alpha 5$ does not occur in association with developing vessels and to date laminin 5 has not been reported to occur at this site. There is also no evidence that integrin $\alpha 6 \beta 4$ on endothelial cells can bind to the laminin $\alpha 4$ chain. Hence, the significance of this laminin receptor on sprouting vessels is not clear.

\section{Lutheran blood group glycoprotein}

More recently, the Lutheran blood group glycoprotein has been described as a specific receptor that binds to laminin $\alpha 5$ (Fig. 5). The Lutheran blood group glycoprotein represents a new 
member of the immunoglobulin superfamily with five extracellular Ig-like domains, a transmembrane domain and a cytoplasmic tail with three potential phosphorylation sites and a proline-rich consensus sequence for binding of Src homology 3 (SH3) domains, suggesting possible involvement in intracellular signaling pathways $(127,128)$ (Fig. 5). The extracellular portion of the Lutheran is highly glycosylated and contains two consensus integrin binding motifs and an RGD-site. In endothelium, it is expressed only post-natally where its appearance coincides precisely with that of laminin $\alpha 5$ in the endothelial cell basement membrane $(117,138)$. Solid phase binding studies utilizing recombinant laminin $\alpha 5$ domains have identified the LG3 domain as the Lutheran binding site (Fig. $5 \& 6$ ) (83). Lutheran has been shown to be upregulated on sickle red cells compared to normal red blood cells, and sickle red cells show increased adhesion to laminin $\alpha 5$ in in vitro assays $(42,98,187)$. In sickle cell disease, detachment of endothelial cells leads to exposure of the subendothelial basement membrane (164) containing high levels of laminin $\alpha 5$. Hence, the involvement of Lutheran-mediated sickle cell binding to laminin $\alpha 5$ is likely to be an important factor in causing vaso-occlusion and painful crisis in sickle-cell disease patients (98). However, the functional significance of Lutheran-laminin $\alpha 5$ interactions in nonpathological situations remains to be investigated.

\section{Dystroglycan}

Dystroglycan exists as an extracellular $\alpha$-subunit and a transmembrane $\beta$-subunit that are the products of the same gene and result from post-translation processing of the molecule $(37,181)$ (Fig. 5). The $\alpha$-dystroglycan subunit acts as an extracellular receptor for several basement membrane components and represents the major non-integrin laminin receptor (37). Dystroglycan constitutes the central part of a larger complex know as the dystrophin-glycoprotein complex (DGC), best known from skeletal muscle where deletions or mutations in several of its components result in muscular dystrophies in both man and in mice $(37,107,181)$. The major components of the DGC of skeletal muscle are shown in Fig. 5. However, the expression of $\alpha-$ dystroglycan on endothelium in vivo remains controversial and the data suggest a differential expression pattern depending on endothelial cell type or possibly tissue type. In vitro studies have demonstrated the expression of dystroglycan on bovine aortic endothelial cells which supports binding to laminin 1 (a non-endothelial cell laminin isoform - see Table 1) (156), and there has been suggestion that $\alpha$-dystroglycan is upregulated on endothelium in vivo during tumour 
angiogenesis (69). However, in non-pathological situations, $\alpha$-dystroglycan is principally associated with vascular smooth muscle cells $(37,38)$. Data from our laboratory has also shown the absence of dystroglycan from the surface of brain capillaries and post-capillary venules in a murine inflammation model, where endothelial and subjacent astrocyte endfeet are separated by a perivascular cuff of infiltrating leukocytes, allowing clear identification of the vascular endothelium (4) (see below). Studies utilizing recombinant laminin G-domains have clearly shown the absence of any interaction between $\alpha$-dystroglycan and laminin $\alpha 4$ but high affinity binding to laminin $\alpha 5$ (Fig. 6) $(73,170,203)$. It is difficult to define whether $\alpha$-dystroglycan contributes to endothelial cell adhesion to the basement membrane due to the early lethality of dystroglycan null mice (E5.5), which die before blood vessels form $(66,67)$. Conditional knockout mouse studies will be necessary to define a function for dystroglycan in the vasculature.

\section{Syndecans}

Apart from the above described bona fide laminin receptors, endothelium expresses cell surface heparan sulphate proteoglycans that can also act as extracellular matrix receptors. Cell surface heparan sulphate proteoglycans all contain a core protein covalently linked to heparan sulphatetype glycosaminoglycan (GAG) side chains. The two main categories are the syndecans, which are transmembrane molecules (31), and the glypicans, which are anchored to the surface via a glycosyl phosphatidyl inositol (GPI) linkage (11). These cell surface heparan sulphate proteoglycans may function as independent receptors binding to heparin-binding domains in extracellular matrix molecules and growth factors, or they can act as cofactors in integrin signaling. For example, integrin $\alpha 5 \beta 1$ and syndecan 4 bind to fibronectin, but both interactions are necessary for formation of focal contacts and intracellular signaling $(78,148)$. Endothelial cells have been reported to express syndecans 1 and 4 and glypicans 1 and 4 (76, 108). At present there is no data on the role of glypicans on vessel formation, but syndecan 1 and 4 have been reported to be induced during neovascularization during wound healing. In addition, both syndecan 1 and syndecan 4 null mice show abnormalities in capillary formation in a skin wound healing model $(40,76)$, consistent with a role in pathological angiogenesis.

The fact that several different receptors can mediate binding to laminin $\alpha 4$ and $\alpha 5$ chains substantiates the hypothesis that laminin isoforms containing these chains convey several 
different signals to endothelial cells, but may also indicate some redundancy, with different receptors conveying the same signal depending on the organ, developmental stage or pathophysiological situation. At present there is little evidence that laminin interactions with any of the above described receptors are involved in early endothelial cell development or tube formation. Even though $\beta 1$ integrins are clearly required for endothelial tube formation and branching, these effects appear to be mediated by interactions with fibronectin surrounding the nascent vessels via integrin $\alpha 5 \beta 1(48,54)$. This is evident from the elimination of integrin $\alpha 5$ subunit in mice, which does not affect early blood vessel formation, but results in failure of dorsal aorta closure and structural abnormalities and leakiness of the yolk sac vessels, resulting in death at E10-E11 (201).

Interestingly, only the phenotype of integrin $\alpha \mathrm{v}$ null mice is consistent with a potential role as a laminin $\alpha 5$ receptor in blood vessels, although this requires further investigation. In vitro studies had implicated the integrin $\alpha v$ series of receptors in blood vessel formation. This was based on the observation that $\alpha v \beta 3$ is upregulated on certain tumour vessels (18), and the ability of cyclic RGD peptides (specific for $\alpha v$-mediated interactions) and a specific integrin $\alpha \mathrm{v}$ antibody (LM609) to block angiogenesis in response to growth factors in tumours and in retinal angiogenesis $(19,20,124)$. However, elimination of the integrin $\alpha \mathrm{v}$ subunit (8) and several of its $\beta$ chain partners, including $\beta 3, \beta 5$, and $\beta 6(70,139,172)$, in mice have failed to show a defect in the development of endothelium, its migration or differentiation. Rather, current data suggest that the $\alpha \mathrm{v}$ integrins are likely to be negative regulators of blood vessel development and that in their absence vessel growth and branching is enhanced (72). Upon vessel maturation, integrin $\alpha v-$ mediated interactions appear to be required for vessel stability, possibly by mediating interactions with mural cells, a function that is consistent with the appearance of laminin $\alpha 5$ in endothelial basement membranes upon maturation and the fact that several murine endothelial cell lines can bind to laminin $\alpha 5$ in a RGD-dependent manner.

\section{Function of Laminin-Endothelial Cell Interactions}

Vessel Formation 
In vitro assays have suggested several potential roles for laminin $\alpha 4$ in angiogenesis. In general, in in vitro adhesion assays both native and recombinant laminin 8 are poor substrates for endothelial cell adhesion, when compared to other laminin isoforms such as laminins 1, 2, and $10 / 11(34,90)$. Binding tends to be of low affinity and is mediated principally by integrins $\alpha 6 \beta 1$ and $\alpha 3 \beta 1$ (90). This low affinity binding to laminin 8 has been interpreted as conducive for cell migration and has been substantiated by in vitro transwell migration assays $(50,51)$, although this data should be viewed with some reservation due to the over simplification of migration processes in such in vitro assays. Recently, several laminin peptides (from laminin $\alpha 1$ and $\gamma 1$ chains) $(134,135)$ or laminin fragments produced in bacterial systems (laminin $\alpha 4)(32,60,61)$ have been described that show inhibitory effects on endothelial tube formation in in vitro assays. However, these peptides and bacterial fragments are not glycosylated and have not been shown to exhibit the correct and complex folding of the native protein, which may be necessary for receptor binding. The endothelial cell binding peptides/fragments also represent very different structural domains and yet have very similar effects. It is, therefore, not clear whether these inhibitory effects reflect a role of laminins in in vivo angiogenesis processes, or whether they influence other protein-protein interactions not related to laminin function.

The possibility exists, however, that not only intact laminin molecules are biologically relevant, but that laminin fragments generated by in vivo protease activity during pathological situations can induce signals different to those induced by the intact molecule. In vitro studies have shown that the C-terminal G-domain of laminin $\alpha 4$ is proteolytically cleaved by as yet undefined proteases, resulting in the release of the last two globular domains (LG4-LG5) (170) and potentially also of peptides such as those mentioned above. Recombinant laminin $\alpha 4$ LG1-3 and LG4-5 fragments have been produced in an eukaryotic cell system and have been shown to exhibit correct folding in rotary shadowing experiments (170). The use of these recombinant proteins in in vitro assays has shown that laminin $\alpha 4$ shows lower binding to sulfatides and to heparin than laminin $\alpha 1$ and $\alpha 2$ chains and, therefore, low affinity interaction with heparan sulphate proteoglycans (either in the basement membrane or on the cell surface) (168-170, 182). These recombinant G-domains also do not bind to nidogens 1 or 2, BM40, collagen types I or IV, or to the cell surface receptor $\alpha$-dystroglycan. Neither laminin $\alpha 4$ LG1-3 nor LG4-5 was found to support high levels of adhesion of several different cell types, including endothelial cells, in in 
vitro assays (as compared to similar domains from laminin $\alpha 1$ or $\alpha 2$ chains). However, laminin a4 LG4-5 but not LG1-3 was shown to inhibit endothelial cell migration in an in vitro wound healing assay, and to perturb tube formation in an in vitro model (170). Although the mode of action of laminin $\alpha 4$ LG4-5 is unclear, it has been proposed to involve interference with integrin $\alpha 6 \beta 1$ and $\alpha 3 \beta 1$-mediated interactions.

These latter data are consistent with the phenotype of the laminin $\alpha 4$ knockout mouse, which exhibits hemorrhages during the late embryonic and neonatal periods (174). The phenotype is rescued by laminin $\alpha 5$ expression, which occurs earlier than in wild type mice, at around birth rather than 3-4 weeks postnatally. Interestingly, neonatal laminin $\alpha 4$ null mice show reduced immunofluorescent staining for collagen type IV, laminin $\beta 1$ and $\gamma 1$ chains and nidogen 1 in endothelial cell basement membranes, but no change in perlecan staining. Electron microscopy also shows clear defects in the endothelial cell basement membrane, with discontinuities in the lamina densa. This suggests that blood vessels can exist even in the absence of laminin and collagen type IV in the basement membrane, and that perlecan is sufficient for early vessel formation. This is substantiated by data from the collagen type IV null mouse (137) and the endothelial cell specific perlecan null mouse (64) (see below). However, the integrity of vessels and their proper maturation requires the presence of laminin 8 , since severe defects are apparent in a cornea angiogenesis model in the laminin $\alpha 4$ null mice $(174,208)$. Blood vessel formation is enhanced in this model, with dilation of vessels, aberrant branching and excessive edema. This suggests that laminin $\alpha 4$ may have two roles: 1) an inhibitory role in early tube formation (at least in the case of pathological angiogenesis), and 2) an instructive role in branching and maturation of vessels in both embryonic and pathological angiogenesis. Whether development of mural cells and their interactions with endothelial cell are normal in the laminin $\alpha 4$ null mice has not been studied to date, and further analysis of the blood vessels of this mouse is required. 


\section{Vessel Stability}

There is little data to suggest that endothelial cell derived laminin $\alpha 5$ is involved in angiogenesis, as its expression occurs late in the formation of blood vessels (161). Rather, the data argue for a role in the stability/maturation of vessels and their barrier function (see below).

The laminin $\alpha 5$ chain has been eliminated in mice resulting in a late embryonic lethality, before laminin $\alpha 5$ appears in endothelial cell basement membranes (109). However, there is evidence from this mouse that glomerular capillaries require cues from laminin $\alpha 5$ present in the glomerular basement membrane for migration into the glomerulus, for capillary looping, and for vessel stability. In the developing kidney, laminin $\alpha 5$ replaces laminin $\alpha 1$ in the glomerular basement membrane at the capillary loop stage, a transition required for glomerulogenesis (111, 163). Mice lacking laminin $\alpha 5$ exhibit avascular glomeruli associated with breakdown of the glomerular basement membrane (111). Using transgenic mice, expressing a chimeric laminin composed of laminin $\alpha 5$ domains VI to I fused to the human laminin $\alpha 1 \mathrm{G}$ domains, bred onto the laminin $\alpha 5$ null background (referred to here as Mr51 x lama5 -/-), glomerular basement membrane breakdown was prevented but glomerular capillaries remained defective (85). Capillary loops did not form and vessels were distended, exhibiting a ballooned appearance. A similar phenotype is seen in mice lacking mesangial cells in the glomerulus due to absence of PDGFB/ PDGF receptor $\beta$ signaling (102). Although mesangial cells were present in the Mr51 $\mathrm{x}$ lama5 -/- mouse strain, their adhesion to the glomerular basement membrane at the bases of capillary loops was defective (85), suggesting a mechanism whereby mesangial cells organize the glomerular capillaries by adhering to the $\mathrm{G}$ domain of laminin $\alpha 5$ in the glomerular basement membrane (via integrin $\alpha 3 \beta 1$ and Lutheran blood group glycoprotein). The similarity between mesangial cells and pericytes suggests that a similar situation may occur in other capillary types, with pericytes binding to laminin $\alpha 5$ (either produced by the endothelium or by the pericytes themselves) organizing and stabilizing the blood vessel. 


\section{Barrier Function}

The endothelial basement membrane is likely to contribute to the barrier function of endothelium by impeding the movement of large, charged molecules and the migration of cells, such as leukocytes and tumour cells. There has been little investigation of the former, but there is accumulating evidence that the endothelial cell basement membrane may influence the movement of leukocytes into inflamed tissues. The best evidence for such a role comes from studies on murine autoimmune encephalomyelitis (EAE) (159). EAE can be actively induced in susceptible mouse strains by immunizing with myelin proteins, myelin fragments, or by adoptive transfer of myelin reactive $\mathrm{CD}^{+} \mathrm{T}$ cell blasts (43) and shares some similarities with the human disease multiple sclerosis (43). The extravasation of autoaggressive $\mathrm{T}$ cells from postcapillary venules into the central nervous system (CNS) parenchyma is critical in this inflammation and is a multistep process, due to the specialized structure of blood vessels in the CNS.

Apart from the endothelial cell monolayer, blood vessels in the CNS are bordered by astrocyte endfeet (Fig. 7). Ultrastructurally, at least two basement membranes can be identified in association with larger blood vessels in the brain, the endothelial and an astroglial basement membrane (196). In addition, the epithelium of the meninges coinvaginates with blood vessels from the surface of the brain and contributes to the astroglial basement membrane $(6,196,207)$. Collectively, the astroglial basement membrane and the meningeal epithelial basement membrane are known as the parenchymal basement membrane, as they delineate the border to the brain parenchyma (Fig. 7).

The biochemical composition of the endothelial and parenchymal basement membranes differ; the endothelial cell basement membrane is characterized by the presence of laminin $\alpha 4$ and $\alpha 5$ chains, while the parenchymal basement membrane contains laminin $\alpha 1$ and $\alpha 2$ chains (159) (Fig. 7). In the course of EAE, leukocytes first penetrate the endothelial basement membrane and, subsequently, accumulate in the perivascular space, defined by the endothelial cell basement membrane and the parenchymal basement membrane, before they penetrate the outer barrier and enter the brain parenchyma to induce disease symptoms. Leukocyte penetration of these two basement membranes have been shown to be distinct steps that are independent of one another (89, 159, 185). $\mathrm{T}$ cell transmigration of the endothelial cell basement membrane occurs 
exclusively at sites defined by the presence of laminin $\alpha 4$ and the absence of laminin $\alpha 5$, suggesting that laminin $\alpha 4$ is permissive for transmigration and laminin $\alpha 5$ is inhibitory (Fig. 7) (4, 159). When EAE is actively induced in laminin $\alpha 4$ knockout mice, which show a compensatory ubiquitous expression of laminin $\alpha 5$ in all blood vessels (174) and no regulatory expression of this chain in response to proinflammatory cytokines, the onset of clinical symptoms of the disease is significantly delayed (Sixt et al., manuscript in preparation) (Fig. 7). Histological analysis of the brains of these mice after disease induction show accumulation of leukocytes in the lumen of the postcapillary venules, suggesting impaired transendothelial migration. Current data from intravital microscopy studies suggest that postcapillary venules are mosaic in their content of laminin $\alpha 4$ and $\alpha 5$, with areas containing little or no laminin $\alpha 5$. Transmigrating $\mathrm{T}$ cells appear to seek sites containing exclusively laminin $\alpha 4$ to transmigrate and avoid those that also contain laminin $\alpha 5$. At present the data suggest that the barrier function conferred by the presence of laminin $\alpha 5$ in basement membranes of postcapillary venules is due to both direct effects on leukocyte adhesion (159), as well as indirect effects on endothelium and leukocytes.

Recently, Patarroyo and coworkers have demonstrated that extravasation of polymorphonuclear granulocyte (PMN) is also influenced by the laminin composition of endothelial cell basement membranes (197). Using a murine peritonitis model, significantly less PMN infiltration into the peritoneal cavity was measured in laminin $\alpha 4$ knockout mice as compared to wildtype littermates, suggesting deficiencies in the transmigration across peritoneal postcapillary venules. However, these authors suggest an additional effect due to PMN secretion of laminin 8 onto their surfaces, which they hypothesize facilitates PMN interaction with the basement membrane and, thereby, its penetration. In order to distinguish between the direct barrier effects of the endothelial basement membrane and potential additional effects due to secretion of laminin 8 onto the PMN surfaces it will be necessary to demonstrate impaired migration of laminin $\alpha 4$ null PMNs as compared to PMNs from wildtype littermates in in vitro assays, or to induce peritonitis in chimeric mice carrying laminin $\alpha 4$ null bone marrow on a wildtype background (studies that are currently underway in our laboratory). Leukocyte secretion of laminins and their potential role in extravasation is an interesting possibility that, however, requires further investigation (52, $53,131)$. 
The endothelial cell basement membrane not only presents a barrier to the movement of leukocytes but also to tumour cells in metastasis. However, few physiologically relevant studies exist in this area, in particular with respect to the endothelial laminins. The only study to date involves the use of the laminin $\alpha 4$ knockout mouse in a lung metastasis model, revealing increased metastases, probably due to the enhanced angiogenesis and pronounced leakiness of newly formed vessels within the primary tumour (208). In addition, the primary tumour showed reduced apoptosis and, therefore, enhanced growth in the laminin $\alpha 4$ knockout mice. Since newly formed blood vessels lack laminin $\alpha 5$ in both wildtype and the laminin $\alpha 4$ knockout mice, presumedly the tumour cells can more readily migrate out of the tumour in the laminin $\alpha 4$ knockout mice due to increased leakiness of vessels, and enhanced growth may result in larger numbers of emigrating cells. However, whether this is sufficient to explain the increased metastasis to the lung remains unclear, where all blood vessels show a compensatory aberrant expression of laminin $\alpha 5$ which, based on the leukocyte studies, one may expect to reduce penetrability of these vessels. The data suggest that the mechanism of tumour cell transmigration of endothelial cell basement membranes differs from that utilized by leukocytes, and that tumour cells may be able to overcome the barrier conferred by the presence of laminin $\alpha 5$.

\section{Endothelial laminins as signal transducers to mural cells/ mechanosensing}

Endothelial cells line the luminal surfaces of all blood vessels and are, therefore, in an ideal position to act as mechanosensers of changes in blood flow and, consequently, shear stress. The endothelium communicates changes in shear stress to other compartments of the vascular wall, which is important for vascular homeostasis. Nitric oxide (NO) produced by endothelial-derived nitric oxide synthase (eNOS) is considered an important factor in such mechanosensing events, leading to cellular responses aimed at adaptions of vessel diameter (57). According to a widely accepted hypothesis, shear stress is sensed by endothelial cells via "focal adhesions", which occur abluminally and consist of aggregations of integrin receptors and linker molecules that interconnect the cytoplasmic tails of the integrins to the actin cytoskeleton (158). Most important, ligand occupation of the integrins is necessary for focal adhesion formation. Increases in shear stress result in the formation of such focal adhesions and intracellular activation of kinases (in particular, focal adhesion kinases (FAK) and mitogen-activated protein kinases (MAPK)), which 
in turn initiate signaling cascades leading to altered gene expression, including upregulation of eNOS (158).

Interactions between the vascular endothelium and laminins in its basement membrane have been implicated in the mechanosensing of changes in shear stress in vessels. Although these laminins have not been shown to be the endothelial cell laminins discussed in this review, this is suggested by the data. In vitro studies have shown shear stress induced upregulation of eNOS only when porcine aortic endothelial cells are plated on laminin 1 (58), while shear stress-induced focal adhesion formation occurs only when human umbilical vein endothelial are plated on a human laminin substrate (80). Laminin 1 does not occur in endothelial cell basement membranes but represents a prototype laminin (Fig. 3) that is readily prepared in large quantities from a mouse Engelbreth-Holm-Swarm (EHS) tumour $(129,179)$ and, therefore, widely used in in vitro cell adhesion and migration assays. However, the experiments performed with laminin 1 report an RGD-dependent adhesion of the porcine aortic endothelial cells to laminin 1 (58). As laminin 1 does not contain an exposed RGD site, this implies that the observed shear stress-induced upregulation of eNOS may stem from adhesion to a substrate produced by the cells themselves and which is either induced by or binds well to the plated laminin 1 substrate. In contrast, commercially available human laminin is typically a laminin 10/11 preparation (see Table 1), isolated from trypsin-treated placenta. It, therefore, reflects one of the endothelial laminins, albeit in a proteolytically processed form. Further, the proposed involvement of integrin $\alpha v \beta 3$ in endothelial cell mechanosensing (80), which as discussed above can act a receptor for the laminin $\alpha 5$ chain of laminin 10 in endothelium, substantiates a potential involvement of endothelial cell laminin 10 in mechanosensing of changes in shear stress. It is also noteworthy in this context that the other major ligands of $\alpha v \beta 3$, vitronectin and fibronectin, are likely to occur in close contact with endothelium only in the provisional matrix of nascent vessels but not in mature and undamaged vessels, as they represent interstitial matrix molecules that occur subjacent to the basement membrane.

Recent evidence suggests that shear force or other pathophysiological stimuli also leads to release of growth factors from vascular endothelial cells, in particular FGF-2, which acts to induce endothelial proliferation and differentiation (resulting in neovascularization that occurs in many 
pathological situations) (59). This growth factor release is dependent on specific integrin $\alpha v \beta 3$ mediated interactions of the endothelial cells with the extracellular matrix and can be blocked by RGD peptides. The $\alpha v \beta 3$ ligand in the vascular endothelial cell basement membrane has not yet been identified, but here too it is noteworthy that $\alpha v \beta 3$ binds laminin $\alpha 5$ in an RGD-dependent manner in endothelial cells.

Clearly the role of endothelial laminins in the physiology of blood vessels is an area that requires further investigation with the physiologically relevant laminin isoforms. The laminin $\alpha 4$ knockout mouse and mice lacking laminin $\alpha 5$ specifically in the endothelial cell basement membranes will be vital to such studies.

\section{Other Endothelial Cell-Associated Extracellular Matrix Molecules}

It is important to note that apart from laminins $\alpha 4$ and $\alpha 5$, several other extracellular matrix molecules are differentially expressed by endothelium depending on developmental stage, endothelium type and/or physiological state. These include SPARC (also known as BM40 and osteonectin), nidogens 1 and 2, thrombospondins 1 and 2, fibronectin, and collagen types VIII, XV and XVIII (Table 2).

Table 2: Minor Endothelial Cell-Associated Extracellular Matrix Molecules

\begin{tabular}{|l|l|l|l|l|l|}
\hline \multicolumn{1}{|c|}{ Molecule } & $\begin{array}{c}\text { *Mol. Mass } \\
\text { (kDa) }\end{array}$ & \multicolumn{1}{|c|}{$\begin{array}{c}\text { In vivo } \\
\text { Localization }\end{array}$} & $\begin{array}{c}\text { Potential } \\
\text { Interactions }\end{array}$ & \multicolumn{1}{|c|}{$\begin{array}{c}\text { Potential } \\
\text { Functions }\end{array}$} & Ref \\
\hline $\begin{array}{l}\text { SPARC/BM40/ } \\
\text { osteonectin }\end{array}$ & 40 & Matricellular & $\begin{array}{l}\text { Collagen I, } \\
\text { vitronectin }\end{array}$ & $\begin{array}{l}\text { Inhibits } \\
\text { endothelial cell } \\
\text { proliferation \& } \\
\text { regulates } \\
\text { activity of } \\
\text { growth factors }\end{array}$ & $(17,199)$ \\
\hline Fibulin 1/ BM90 & 90 (monomer) & $\begin{array}{l}\text { Some endothelial } \\
\text { basement membranes } \\
\text { \& elastic fibres }\end{array}$ & $\begin{array}{l}\text { Nidogen 1, } \\
\text { fibronectin, } \\
\text { endostatin, } \\
\text { laminin 1 \& } \\
\text { perlecan in the } \\
\text { case of fibulin 2 }\end{array}$ & $\begin{array}{l}\text { May represent } \\
\text { an alternative to } \\
\text { nidogen 1 for } \\
\text { cross-linking } \\
\text { basement } \\
\text { membrane } \\
\text { components }\end{array}$ & $(180)$ \\
\hline
\end{tabular}




\begin{tabular}{|c|c|c|c|c|c|}
\hline $\begin{array}{l}\text { Thrombospondin } \\
\text { I \& II }\end{array}$ & $\begin{array}{l}145 \\
\text { (homotrimer) }\end{array}$ & $\begin{array}{l}\text { Matricellular/ } \\
\text { endothelial cell } \\
\text { surfaces; upregulated } \\
\text { in pathological } \\
\text { situations; } \\
\text { thrombospondin II } \\
\text { occurs in association } \\
\text { with developing } \\
\text { vessels }\end{array}$ & $\begin{array}{l}\text { Syndecans, } \\
\text { CD36, } \\
\text { fibrinogen, } \\
\text { fibrin, } \\
\text { collagen V, } \\
\text { fibronectin, } \\
\text { laminin-1 }\end{array}$ & Anti-angiogenic & $(2,14)$ \\
\hline Fibronectin & $\begin{array}{l}250 \\
\text { (homodimer) }\end{array}$ & $\begin{array}{l}\text { Provisional matrix of } \\
\text { developing vessels, } \\
\text { or interstitial matrix } \\
\text { of mature vessels }\end{array}$ & $\begin{array}{l}\text { Perlecan, } \\
\text { fibulins, } \\
\text { laminin } 1\end{array}$ & Pro-angiogenic & $(54,116)$ \\
\hline Collagen VIII & $\begin{array}{l}60 \\
\text { (heterotrimer) }\end{array}$ & $\begin{array}{l}\text { Human endothelial } \\
\text { BMs; some mouse } \\
\text { endothelial BMs }\end{array}$ & Not known & $\begin{array}{l}\text { Confers } \\
\text { resistance to } \\
\text { compression \& } \\
\text { maintains an } \\
\text { open porous \& } \\
\text { translucent } \\
\text { structure }\end{array}$ & (157) \\
\hline $\begin{array}{l}\text { Collagen XV, } \\
\text { C-terminal } \\
\text { fragment is restin }\end{array}$ & $\begin{array}{l}116-139 \\
\text { (homotrimer) } \\
22-25\end{array}$ & Most capillaries & $\begin{array}{l}\text { Fibulin } 2 \text {, } \\
\text { nidogen } 2\end{array}$ & $\begin{array}{l}\# \text { Anti- } \\
\text { angiogenic }\end{array}$ & \multirow[t]{2}{*}{$\begin{array}{c}(133, \\
150,151)\end{array}$} \\
\hline $\begin{array}{l}\text { Collagen XVIII, } \\
\text { C-terminal } \\
\text { fragment is } \\
\text { endostatin }\end{array}$ & $\begin{array}{l}\text { 180-200 } \\
\text { (homotrimer) } \\
22\end{array}$ & $\begin{array}{l}\text { Most capillaries \& } \\
\text { fenestrated } \\
\text { endothelium of } \\
\text { glomerulus, } \\
\text { discontinous } \\
\text { endothelium of liver } \\
\text { sinusoids, splenic } \\
\text { sinusoids \& } \\
\text { capillaries of lung } \\
\text { alveoli }\end{array}$ & $\begin{array}{l}\text { Fibulin } 2 \text {, } \\
\text { nidogen } 2 \text {, } \\
\text { nidogen } 1 \\
\text { laminin } 1 / \\
\text { nidogen } 1 \\
\text { complex, } \\
\text { weak fibulin } 1 \\
\text { binding }\end{array}$ & $\begin{array}{l}\# \text { Anti- } \\
\text { angiogenic }\end{array}$ & \\
\hline
\end{tabular}

* $\mathrm{kDa}$ refers to the monomer/ fragment; \# the function of collagens type XV and XVIII are largely undefined, the anti-angiogenic effects of the $\mathrm{C}$-terminal fragments remain controversial.

Many of these molecules have been eliminated in mice but do not show defects in blood vessel formation during embryogenesis. Nevertheless, the data suggests that they may have specific functions in defined pathological situations (inflammation, metastasis), which requires further investigation. For example, nidogen 2 is highly expressed in endothelial cell basement membranes, as compared to nidogen 1, regardless of the age of the mouse (88), but there is no developmental blood vessel phenotype either in single knockouts $(118,154)$ or in double nidogen 1 and 2 knockout mice (R. Nischt and N. Smyth personal communication). Similarly, collagen type XV and XVIII are both localized in the basement membrane of most capillaries, with collagen type XVIII but not collagen type XV occurring in association with the fenestrated endothelium of the glomerulus, the discontinous endothelium of liver sinusoids and splenic 
sinusoids, and capillaries of lung alveoli (184). Collagen types XVIII and XV are best known for their reported anti-angiogenic activities of their C-terminal domains, endostatin and restin, respectively, which are released by proteolytic cleavage $(123,150,151)$. However, this issue remains highly debatable. Endostatin is present at concentrations in the serum that would efficiently inhibit endothelial cell proliferation in vitro, leading to the suggestion that this circulating form may be involved in the homeostatic control of angiogenesis. However, elimination of one or both of these collagens does not affect angiogenesis in the embryo, and the only blood vessel related defect identified to date is a delay in the postnatal regression of hyaloid capillaries in the retina due to loss of collagen type XVIII (202). It can also not be excluded that the C-terminal fragments of collagen type XV and XVIII play a role in pathological angiogenesis (13).

Thrombospondins and SPARC (also known as BM40 or osteonectin) belong to a group of proteins that have been defined as "matricellular", to denote a subset of extracellular matrix molecules whose properties could be distinguished from structural macromolecules on the one hand, and more bioactive proteins such as cytokines, growth factors and proteases on the other hand $(14,16)$. They are not true basement membrane molecules as they occur at the cell surface but interact with basement membrane components. Thrombospondin 2 occurs primarily in association with developing vessels $(14,15)$, while both thrombospondin 1 and 2 are associated with endothelial cells in pathological conditions (wound healing and tumours) $(15,94,95)$. Both thrombospondin 1 and 2 are potent inhibitors of angiogenesis (1,94). Thrombospondin 1 can activate TGF $\beta$ and act as a negative regulator of MMP9 activation (143). TGF $\beta$ in turn can upregulate tissue inhibitors of metalloproteinases (TIMPs) and MMP 9 is a known activator of angiogenesis by its ability to release VEGF from the extracellular matrix. Thrombospondin 1 also binds CD36 on endothelial cells and activates apoptotic pathways (81). Multiple adhesive interactions have been identified for the thromobospondins including several plasma proteins such as fibrinogen, thrombin, and urokinase, and the extracellular matrix molecules fibronectin, collagen V and heparan sulphate proteoglycans (mainly syndecans). SPARC is associated with developing vessels and with vessels of tumours $(17,93)$. Unlike the thrombospondins, it is not an adhesive molecule but alters cell adhesion to other substrates and cell shape, it inhibits endothelial cell proliferation and regulates the activity of growth factors, such as FGF-2, PDGF 
and VEGF. Elimination of SPARC, thrombopondins 1 or 2 in mice does not have any effect on angiogenesis in the embryo $(56,122,199)$. However, increased vascular density has been reported in tumour angiogenesis models in both thrombospondin 1 and 2 null mice, consistent with a role as negative regulators of pathological vessel growth $(27,194)$.

It is worth mentioning collagen type VIII in this review as it is often used as a marker of blood vessels in vivo. Collagen type VIII is a short non-fibrillar collagen produced by endothelial cells and is localized in or close to most endothelial cell basement membranes in human but not in mouse tissues, where only few vessels contain collagen type VIII (157). In all species, collagen type VIII occurs in the thick corneal endothelial basement membrane, Descemet's membrane, where it forms a regular hexagonal array. It has been suggested that the hexagonal lattice structure of Descement's membrane represents a structural solution to the problem of creating a matrix that can resist compression, yet maintain an open porous and translucent structure. How collagen type VIII interacts with other basement membrane components is not known and its functional significance in endothelial cell basement membranes remains to be determined.

Only for some basement membrane molecules has clear evidence been provided by targeted gene elimination in mice for a role in blood vessel formation or stability, in particular fibronectin, fibulin-1, perlecan and collagen type IV. The best evidence exists for fibronectin and its receptor $\alpha 5 \beta 1(48,54,201)$ : Although endothelial cells form in the absence of fibronectin or $\alpha 5 \beta 1$, studies involving embryoid bodies derived from integrin $\alpha 5$ or fibronectin null embryonic stem cells have shown that the defect lies primarily in branching and stability of the primary vessel plexus (171), which is consistent with a role for fibronectin in the provisional matrix surrounding sprouting nascent vessels during embryogenesis.

Elimination of the collagen type IV $[\alpha 1(\mathrm{IV}) 2 \alpha 2(\mathrm{IV})]$ in mice been recently shown to develop up to E10.5-E11.5 of gestation, whereupon ruptures in Reichert's membrane result in death (137). Interestingly, blood vessels form in these mice, but both large and small vessels show aberrant branching and are leaky and instable, even though pericyte recruitment appears normal. In view of the hypothesis that collagen type IV provides the scaffold integrating other basement membrane components, such as the laminins, nidogen and perlecan, it is interesting that although 
these molecules are secreted and incorporated into networks in the collagen type IV knockout mouse, a gradual reduction in staining for these molecules was apparent, suggesting that they were not retained within the basement membrane in the absence of collagen type IV. The data suggest a role for collagen type IV in vessel integrity under conditions of increasing mechanical demands.

Mice lacking perlecan specifically in endothelial cell basement membranes (64) and fibulin 1 knockout mice (92) show a surprisingly similar blood vessel phenotype, even though neither of these molecules occur exclusively in endothelial cell basement membranes. In both cases, dilations and bleeding occur in microvessels but not larger vessels, appearing at mid-gestation and leading to perinatal death. Vessels affected occur predominantly in skin, heart, gut and brain, however, endothelial cell development and recruitment of pericytes and smooth muscle cells appear normal. Although the basement membrane of affected vessels appears abnormal at the ultrastructural level in the endothelial cell specific perlecan null mouse (64), this is not the case in the fibulin 1 null mouse. The data suggest that the fibulin 1 phenotype may in part be due to loss of interactions with perlecan, one of its main binding partners and, consequently, reduced crosslinking to other endothelial cell basement membrane components, resulting in basement membrane instability without apparent ultrastructural changes (180). In vitro differentiation of perlecan null embryonic stem cells in embryoid bodies has revealed a reduced efficiency to form blood vessels, which can be rescued by addition of FGF-2 (64). This suggests that perlecan may have direct effects as an adhesive molecule on vessel formation, but also modulates angiogenesis by presenting growth factors to endothelial cells.

Taken together the data suggests that endothelial cells can form in the absence of any one of the major basement membrane components, including collagen type IV, perlecan, and nidogens, or in the absence of fibronectin as a major component of the provisional matrix surround forming vessels. Whether or not blood vessels can form without any laminin is not yet clear and would require generation of a mouse lacking the ubiquitously expressed laminin $\gamma 1$ chain specifically in endothelium. However, the laminin $\alpha 4$ null mice provide some insight to the role of laminins in vessel formation and suggest that also laminins are not essential for endothelial cell formation. Rather, the loss of any one of the major endothelial cell basement membrane components has 
clear consequences on vessel branching and/or stability and differentiation of specialized vessels. Much of this data has come from mice lacking basement membrane components at all sites, which results in various defects and complicates the analysis of blood vessel phenotypes. It is now necessary to generate mice that selectively lack basement membrane components in endothelial basement membranes, in order to better define their precise role on vessel stability or physiology.

\section{Conclusion:}

Although considerable advances have been made on deciphering the genes and soluble factors involved in vessel formation both in the embryo and in pathological situations, relatively little is known about cell-extracellular matrix interactions that may either directly or indirectly contribute to these processes. We are only just starting to understand the complexity of the endothelial cell basement membrane and its dynamic nature. This is certainly related to the difficult nature of basement membrane molecules, which are typically large, highly glycosylated, oligomeric molecules with the tendency to aggregate. As a consequence, isolation of these molecules without tissue digestion and denaturation of proteins is difficult and their use in in vitro structure-function assays has been limited to those few molecules that can be isolated in sufficient quantity and quality, e.g. laminin 1, fibronectin, vitronectin, thrombospondin 1. Therefore, the establishment of modified pCEP4 (136) or pCis vectors (205) and the use of HEK293 cells (human kidney epithelial cell line) for production of basement membrane proteins or fragments thereof has been a significant achievement in basement membrane research. Both are widely used for production of various extracellular matrix and receptor molecules and are equally effective for both mouse and human proteins. To date molecules that have been recombinantly produced using this mammalian system include intact laminins 1,8 and $10(34,90,205)$ and various laminin-1 fragments, BM40, nidogen-1, fibulins, perlecan fragments, endostatin, integrins $\alpha 6$ and $\alpha 7$, and $\alpha$-dystroglycan, to name just a few.

With sufficient amounts of purified recombinant protein and the advent of sophisticated protein cystallography and NMR techniques, the three dimensional structure of basement membrane proteins or specific domains thereof can now be determined. This information is crucial to the 
development of models of how such molecules interact either with themselves and other proteins in basement membrane formation, or with their ligands on the cell surface or in the interstitium. Furthermore, co-crystallography techniques will allow definition of protein-protein interactions important for structure-function relationships. These techniques will also facilitate a more detailed analysis of growth factor binding to extracellular matrix molecules, or structural domains thereof, and their presentation to cell surface receptors. Such studies will provide insight into the different signals that can be induced by growth factors. An example of this is the recent discovery that VEGF-A signal different information to blood vessel endothelium when it is perceived by the endothelium bound to heparin as opposed to in the soluble form (146). Only heparin-bound VEGF-A, which probably reflects VEGF-A bound to basement membrane components or cell surface heparan sulfate proteoglycans in vivo, induces enhanced branching of the endothelium.

Precise information on the expression of basement membrane molecules and their ligands in particular tissues or at particular stages of development provide the necessary information for "targeted" elimination of expression, and molecular techniques now allow the design of precise genetic modifications in the mouse. Not only can defined nucleotide changes be engineered into the genome of the mouse, but genetic switches can be designed to target expression or ablation of any gene (for which molecular information is available) to any tissue at any defined time. The structure-function relationships defined by the in vitro methods discussed above will further permit identification of target sites in extracellular matrix molecules and/or growth factors for mutation and, subsequent, testing in mouse models for their effects on the endothelium.

\section{Acknowledgements}

The authors wish to thank Smriti Agrawal for careful reading of the manuscript. 


\section{Citations}

1. Adams JC. Thrombospondins: multifunctional regulators of cell interactions. Annu Rev Cell Dev Biol 17: 25-51, 2001.

2. Adams JC and Lawler J. The thrombospondins. Int J Biochem Cell Biol 36: 961-968, 2004.

3. Adams RH, Wilkinson GA, Weiss C, Diella F, Gale NW, Deutsch U, Risau W, and Klein R. Roles of ephrinB ligands and EphB receptors in cardiovascular development: demarcation of arterial/venous domains, vascular morphogenesis, and sprouting angiogenesis. Genes Dev 13: 295-306, 1999.

4. Agrawal S, Durbeej M, Sixt M, Korner H, Nelissen I, Opdenakker G, and Sorokin LM. Gelatinases Selectively Cleave Dystroglycan during Leukocyte Infiltration of the Central Nervous System. submitted.

5. Aird WC, Edelberg JM, Weiler-Guettler H, Simmons WW, Smith TW, and Rosenberg RD. Vascular bed-specific expression of an endothelial cell gene is programmed by the tissue microenvironment. J Cell Biol 138: 1117-1124, 1997.

6. Alcolado R, Weller RO, Parrish EP, and Garrod D. The cranial arachnoid and piamater in man: anatomical and ultrastructural observations. Neuropathol Appl Neurobiol 14: 1-17, 1988.

7. Arahata K, Ishii H, and Hayashi YK. Congenital muscular dystrophies. Curr Opin Neurol 8: 385-390, 1995.

8. Bader BL, Rayburn H, Crowley D, and Hynes RO. Extensive vasculogenesis, angiogenesis and organogenesis precede lethality in mice lacking all $\alpha \mathrm{v}$ integrins. Cell 95: 507-519, 1998.

9. Battersby S, Critchley HO, Morgan K, Millar RP, and Jabbour HN. Expression and regulation of the prokineticins (endocrine gland-derived vascular endothelial growth factor and $\mathrm{Bv} 8$ ) and their receptors in the human endometrium across the menstrual cycle. J Clin Endocrinol Metab 89: 2463-2469, 2004.

10. Beck K, Hunter I, and Engel J. Structure and function of laminin: anatomy of a multidomain glycoprotein. FASEB J 4: 148-160, 1990.

11. Bernfield M, Gotte M, Park PW, Reizes O, Fitzgerald ML, Lincecum J, and Zako M. Functions of cell surface heparan sulfate proteoglycans. Annu Rev Biochem 68: 729-777, 1999.

12. Bezakova G and Ruegg MA. New insights into the roles of agrin. Nat Rev Mol Cell Biol 4: 295-308, 2003.

13. Bloch W, Huggel K, Sasaki T, Grose R, Bugnon P, Addicks K, Timpl R, and Werner S. The angiogenesis inhibitor endostatin impairs blood vessel maturation during wound healing. FASEB J 14: 2373-2376, 2000.

14. Bornstein P. Thrombospondins as matricellular modulators of cell function. $J$ Clin Invest 107: 929-934, 2001.

15. Bornstein P, Armstrong LC, Hankenson KD, Kyriakides TR, and Yang Z. Thrombospondin 2, a matricellular protein with diverse functions. Matrix Biol 19: 557-568, 2000.

16. Bornstein P and Sage EH. Thrombospondins. Methods Enzymol 245: 62-85, 1994.

17. Brekken RA and Sage EH. SPARC, a matricellular protein: at the crossroads of cell-matrix. Matrix Biol 19: 569-580, 2000. 
18. Brooks PC, Clark RA, and Cheresh DA. Requirement of vascular integrin $\alpha v \beta 3$ for angiogenesis. Science 264: 569-571, 1994.

19. Brooks PC, Montgomery AM, Rosenfeld M, Reisfeld RA, Hu T, Klier G, and Cheresh DA. Integrin $\alpha v \beta 3$ antagonists promote tumor regression by inducing apoptosis of angiogenic blood vessels. Cell 79: 1157-1164, 1994.

20. Brooks PC, Stromblad S, Klemke R, Visscher D, Sarkar FH, and Cheresh DA. Antiintegrin $\alpha v \beta 3$ blocks human breast cancer growth and angiogenesis in human skin. J Clin Invest 96: 1815-1822, 1995.

21. Burri PH, Hlushchuk R, and Djonov V. Intussusceptive angiogenesis: its emergence, its characteristics, and its significance. Dev Dyn 231: 474-488, 2004.

22. Cao R, Eriksson A, Kubo H, Alitalo K, Cao Y, and Thyberg J. Comparative evaluation of FGF-2-, VEGF-A-, and VEGF-C-induced angiogenesis, lymphangiogenesis, vascular fenestrations, and permeability. Circ Res 94: 664-670, 2004.

23. Carmeliet P. Angiogenesis in health and disease. Nat Med 9: 653-660, 2003.

24. Carmeliet P. Mechanisms of angiogenesis and arteriogenesis. Nat Med 6: 389-395, 2000.

25. Carmeliet $\mathbf{P}$ and Jain RK. Angiogenesis in cancer and other diseases. Nature 407: 249-257, 2000.

26. Chambers RC, Leoni P, Kaminski N, Laurent GJ, and Heller RA. Global expression profiling of fibroblast responses to transforming growth factor-betal reveals the induction of inhibitor of differentiation-1 and provides evidence of smooth muscle cell phenotypic switching. Am J Pathol 162: 533-546, 2003.

27. Chen H, Herndon ME, and Lawler J. The cell biology of thrombospondin-1. Matrix Biol 19: 597-614, 2000.

28. Christiano AM and Uitto J. Molecular complexity of the cutaneous basement membrane zone. Revelations from the paradigms of epidermolysis bullosa. Exp Dermatol 5: 1-11, 1996.

29. Cleaver O and Melton DA. Endothelial signaling during development. Nat Med 9: 661-668, 2003.

30. Colognato H, Winkelmann DA, and Yurchenco PD. Laminin polymerization induces a receptor-cytoskeletal network. J Cell Biol 145: 619-631, 1999.

31. Couchman JR. Syndecans: proteoglycan regulators of cell-surface microdomains? Nat Rev Mol Cell Biol 4: 926-937, 2003.

32. DeHahn KC, Gonzales M, Gonzalez AM, Hopkinson SB, Chandel NS, Brunelle JK, and Jones JC. The $\alpha 4$ laminin subunit regulates endothelial cell survival. Exp Cell Res 294: 281289, 2004.

33. Delwel GO and Sonnenberg A. Laminin isoforms and their integrin receptors. In: Adhesion receptors as therapeutic targets., edited by Horton MA. London: CRC Press, 1996, p. 9-36.

34. Doi M, Thyboll J, Kortesmaa J, Jansson K, Iivanainen A, Parvardeh M, Timpl R, Hedin U, Swedenborg J, and Tryggvason K. Recombinant human laminin-10 ( $\alpha 5 \beta 1 \gamma 1)$. Production, purification, and migration-promoting activity on vascular endothelial cells. $J$ Biol Chem 277: 12741-12748, 2002.

35. Doolittle RF. Reconstructing history with amino acid sequences. Science 1: 192-200, 1992.

36. Dowling J, Yu QC, and Fuchs E. $\beta 4$ integrin is required for hemidesmosome formation, cell adhesion and cell survival. J Cell Biol 134: 559-572, 1996.

37. Durbeej M, Henry M, and Campbell KP. Dystroglycan in development and disease. Curr Opin Cell Biol 10: 594-601, 1998. 
38. Durbeej M, Henry MD, Ferletta M, Campbell KP, and Ekblom P. Distribution of dystroglycan in normal adult mouse tissues. J Histochem Cytochem 46: 449-458, 1998.

39. Dvorak HF. Vascular permeability factor/vascular endothelial growth factor: a critical cytokine in tumor angiogenesis and a potential target for diagnosis and therapy. J Clin Oncol 20: 4368-4380, 2002.

40. Echtermeyer F, Streit M, Wilcox-Adelman S, Saoncella S, Denhez F, Detmar M, and Goetinck P. Delayed wound repair and impaired angiogenesis in mice lacking syndecan-4. $J$ Clin Invest 107: R9-R14, 2001.

41. Eichmann A, Pardanaud L, Yuan L, and Moyon D. Vasculogenesis and the search for the hemangioblast. J Hematother Stem Cell Res 11: 207-214, 2002.

42. El Nemer W, Gane P, Colin Y, Bony V, Rahuel C, Galacteros F, Cartron JP, and Le Van Kim C. The Lutheran blood group glycoproteins, the erythroid receptors for laminin, are adhesion molecules. J Biol Chem 273: 16686-16693, 1998.

43. Engelhardt B. Lymphocyte trafficking through the central nervous system. In: Adhesion Molecules and Chemokines in Lymphocyte Trafficking., edited by Hamann A. Amsterdam: Harwood Academic Publishers, 1997, p. 173-200.

44. Ferrara N. VEGF and the quest for tumour angiogenesis factors. Nat Rev Cancer 2: 795803, 2002.

45. Ferrara N, Gerber HP, and LeCouter J. The biology of VEGF and its receptors. Nat Med 9: 669-676, 2003.

46. Flamme I, Frolich T, and Risau W. Molecular mechanisms of vasculogenesis and embryonic angiogenesis. J Cell Physiol 173: 206-210, 1997.

47. Fox JW, Mayer U, Nischt R, Aumailley M, Reinhardt D, Wiedermann H, Mann K, Timpl R, Krieg T, Engel J, and Chu M-L. Recombinant nidogen consists of three globular domains and mediates binding of laminin to collagen type IV. EMBO J 10: 3136-3146, 1991.

48. Francis SE, Goh KL, Hodivala-Dilke K, Bader BL, Stark M, Davidson D, and Hynes RO. Central roles of $\alpha 5 \beta 1$ integrin and fibronectin in vascular development in mouse embryos and embryoid bodies. Arterioscler Thromb Vasc Biol 22: 927-933, 2002.

49. Frieser M, Nöckel H, Pausch F, Röder C, Hahn A, Deutzmann R, and Sorokin LM. Cloning of the mouse laminin $\alpha 4$ gene: expression in a subset of endothelium. Eur $J$ Biochem 246: 727-735, 1997.

50. Fujiwara H, Gu J, and Sekiguchi K. Rac regulates integrin-mediated endothelial cell adhesion and migration on laminin-8. Exp Cell Res 292: 67-77, 2004.

51. Fujiwara H, Kikkawa Y, Sanzen N, and Sekiguchi K. Purification and characterization of human laminin-8. Laminin-8 stimulates cell adhesion and migration through $\alpha 3 \beta 1$ and $\alpha 6 \beta 1$ integrins. J Biol Chem 276: 17550-17558, 2001. 
52. Geberhiwot T, Assefa D, Kortesmaa J, Ingerpuu S, Pedraza C, Wondimu Z, Charo J, Kiessling R, Virtanen I, Tryggvason K, and Patarroyo M. Laminin-8 ( $\alpha 4 \beta 1 \gamma 1)$ is synthesized by lymphoid cells, promotes lymphocyte migration and costimulates $\mathrm{T}$ cell proliferation. J Cell Sci 114: 423-433, 2001.

53. Geberhiwot T, Ingerpuu S, Pedraza C, Neira M, Lehto U, Virtanen I, Kortesmaa J, Tryggvason K, Engvall E, and Patarroyo M. Blood platelets contain and secrete laminin-8 ( $\alpha 4 \beta 1 \gamma 1)$ and adhere to laminin-8 via $\alpha 6 \beta 1$ integrin. Exp Cell Res 253: 723-732, 1999.

54. George EL, Georges-Labouesse EN, Patel-King RS, Rayburn H, and Hynes RO. Defects in mesoderm, neural tube and vascular development in mouse embryos lacking fibronectin. Development 119: 1079-1091., 1993.

55. Georges-Labouesse E, Messaddeq N, Yehia G, Cadalbert L, Dierich A, and Le Meur M. Absence of integrin $\alpha 6$ leads to epidermolysis bullosa and neonatal death in mice. Nat Genetics 13: 370-373, 1996.

56. Gilmour DT, Lyon GJ, Carlton MB, Sanes JR, Cunningham JM, Anderson JR, Hogan BL, Evans MJ, and Colledge WH. Mice deficient for the secreted glycoprotein SPARC/osteonectin/BM40 develop normally but show severe age-onset cataract formation and disruption of the lens. EMBO J 17: 1860-1870, 1998.

57. Gloe T and Pohl U. Laminin binding conveys mechanosensing in endothelial cells. News Physiol Sci 17: 166-169, 2002.

58. Gloe T, Riedmayr S, Sohn HY, and Pohl U. The $67-\mathrm{kDa}$ laminin-binding protein is involved in shear stress-dependent endothelial nitric-oxide synthase expression.

J Biol Chem 274: 15996-16002, 1999.

59. Gloe T, Sohn HY, Meininger GA, and Pohl U. Shear stress-induced release of basic fibroblast growth factor from endothelial cells is mediated by matrix interaction via integrin avß3. J Biol Chem 277: 23453-23458, 2002.

60. Gonzales M, Weksler B, Tsuruta D, Goldman RD, Yoon KJ, Hopkinson SB, Flitney FW, and Jones JC. Structure and function of a vimentin-associated matrix adhesion in endothelial cells. Mol Biol Cell 12: 85-100, 2001.

61. Gonzalez AM, Gonzales M, Herron GS, Nagavarapu U, Hopkinson SB, Tsuruta D, and Jones JC. Complex interactions between the laminin $\alpha 4$ subunit and integrins regulate endothelial cell behavior in vitro and angiogenesis in vivo. Proc Natl Acad Sci USA 99: 16075-16080, 2002.

62. Goumans MJ, Lebrin F, and Valdimarsdottir G. Controlling the angiogenic switch: a balance between two distinct TGF- $\beta$ receptor signaling pathways. Trends Cardiovasc Med 13: 301-307, 2003.

63. Goumans MJ, Valdimarsdottir G, Itoh S, Rosendahl A, Sideras P, and ten Dijke P. Balancing the activation state of the endothelium via two distinct TGF- $\beta$ type I receptors. EMBO J 21: 1743-1753, 2002.

64. Gustafsson E, Cramnert C, Bloch W, Costell M, Kreel W, Weidle U, Addicks K, Timpl $\mathbf{R}$, and Fässler R. Perlecan maitains microvessel integrity in vivo and modulates angiogenesis in vitro. submitted.

65. Hellström M, Kal NM, Lindahl P, Abramsson A, and Betsholtz C. Role of PDGF-B and PDGFR- $\beta$ in recruitment of vascular smooth muscle cells and pericytes during embryonic blood vessel formation in the mouse. Development 126: 3047-3055, 1999.

66. Henry MD and Campbell KP. A role for dystroglycan in basement membrane assembly. Cell 95: 859-870, 1998. 
67. Henry MD, Williamson RA, and Campbell KP. Analysis of the role of dystroglycan in early postimplantation mouse development. Ann N Y Acad Sci 857: 256-259, 1998.

68. Hohenester $\mathbf{E}$ and Engel J. Domain structure and organisation in extracellular matrix proteins. Matrix Biol 21: 115-128, 2002.

69. Hosokawa H, Ninomiya H, Kitamura Y, Fujiwara $\mathbf{K}$, and Masaki T. Vascular endothelial cells that express dystroglycan are involved in angiogenesis. J Cell Sci 115: 1487-1496, 2002.

70. Huang XZ, Wu JF, Cass D, Erle DJ, Corry D, Young SG, Farese RV, Jr., and Sheppard D. Inactivation of the integrin $\beta 6$ subunit gene reveals a role of epithelial integrins in regulating inflammation in the lung and skin. J Cell Biol 133: 921-928, 1996.

71. Hudson BG, Reeders ST, and Tryggvason K. Type IV collagen: structure, gene organization, and role in human diseases. Molecular basis of Goodpasture and Alport syndromes and diffuse leiomyomatosis. J Biol Chem 268: 26033-26036, 1993.

72. Hynes RO. A reevaluation of integrins as regulators of angiogenesis. Nat Med 8: 918-921, 2002.

73. Ido H, Harada K, Futaki S, Hayashi Y, Nishiuchi R, Natsuka Y, Li S, Wada Y, Combs AC, Ervasti JM, and Sekiguchi K. Molecular dissection of the $\alpha$-dystroglycan- and integrin-binding sites within the globular domain of human laminin-10. J Biol Chem 279: 10946-10954, 2004.

74. Igarashi J, Erwin PA, Dantas AP, Chen H, and Michel T. VEGF induces S1P1 receptors in endothelial cells: Implications for cross-talk between sphingolipid and growth factor receptors. Proc Natl Acad Sci USA 100: 10664-10669, 2003.

75. Iivanainen A, Sainio K, Sariola $\mathbf{H}$, and Tryggvason $\mathbf{K}$. Primary structure and expression of a novel human laminin $\alpha 4$ chain. FEBS Lett 365: 183-188, 1995.

76. Iivanainen E, Kahari VM, Heino J, and Elenius K. Endothelial cell-matrix interactions. Microsc Res Tech 60: 13-22, 2003.

77. Iozzo RV. Heparan sulfate proteoglycans: intricate molecules with intriguing functions. $J$ Clin Invest 108: 165-167, 2001.

78. Ishiguro K, Kadomatsu K, Kojima T, Muramatsu H, Tsuzuki S, Nakamura E, Kusugami K, Saito H, and Muramatsu T. Syndecan-4 deficiency impairs focal adhesion formation only under restricted conditions. J Biol Chem 275: 5249-5252, 2000.

79. Jain RK. Molecular regulation of vessel maturation. Nat Med 9: 685-693, 2003.

80. Jalali S, del Pozo MA, Chen K, Miao H, Li Y, Schwartz MA, Shyy JY, and Chien S. Integrin-mediated mechanotransduction requires its dynamic interaction with specific extracellular matrix (ECM) ligands. Proc Natl Acad Sci USA 98: 1042-1046, 2001.

81. Jimenez B, Volpert OV, Crawford SE, Febbraio M, Silverstein RL, and Bouck N. Signals leading to apoptosis-dependent inhibition of neovascularization by thrombospondin1. Nat Med 6: 41-48, 2000.

82. Johnson C, Sung HJ, Lessner SM, Fini ME, and Galis ZS. Matrix metalloproteinase-9 is required for adequate angiogenic revascularization of ischemic tissues: potential role in capillary branching. Circ Res 94: 262-268, 2004.

83. Kikkawa Y, Moulson CL, Virtanen I, and Miner JH. Identification of the binding site for the Lutheran blood group glycoprotein on laminin $\alpha 5$ through expression of chimeric laminin chains in vivo. J Biol Chem 277: 44864-44869, 2002. 
84. Kikkawa Y, Sanzen N, Fujiwara H, Sonnenberg A, and Sekiguchi K. Integrin binding specificity of laminin-10/11: laminin-10/11 are recognized by $\alpha 3 \beta 1, \alpha 6 \beta 1$ and $\alpha 6 \beta 4$ integrins. J Cell Sci 113: 869-876, 2000.

85. Kikkawa Y, Virtanen I, and Miner JH. Mesangial cells organize the glomerular capillaries by adhering to the $\mathrm{G}$ domain of laminin $\alpha 5$ in the glomerular basement membrane. $J$ Cell Biol 161: 187-196, 2003.

86. Kivirikko S, McGrath JA, Baudoin C, Aberdam D, Ciatti S, Dunnill MG, McMillan JR, Eady RA, Ortonne JP, and Meneguzzi G. A homozygous nonsense mutation in the $\alpha 3$ chain gene of laminin 5 (LAMA3) in lethal (Herlitz) junctional epidermolysis bullosa. Hum Mol Genet 4: 959-962, 1995.

87. Kluk MJ, Colmont C, Wu MT, and Hla T. Platelet-derived growth factor (PDGF)-induced chemotaxis does not require the $G$ protein-coupled receptor S1P1 in murine embryonic fibroblasts and vascular smooth muscle cells. FEBS Lett 533: 25-28, 2003.

88. Kohfeldt E, Sasaki T, Gohring W, and Timpl R. Nidogen-2: a new basemen membrane protein with diverse binding properties. J Mol Biol 282: 99-109, 1998.

89. Körner H, Lemckert FA, Chaudhri G, Etteldorf S, and Sedgwick JD. Tumor necrosis factor blockade in actively induced experimental autoimmune encephalomyelitis prevents clinical disease despite activated $\mathrm{T}$ cell infiltration to the central nervous system. Eur $J$ Immunol 27: 1973-1981, 1997.

90. Kortesmaa J, Yurchenco P, and Tryggvason K. Recombinant laminin-8 (alpha4, beta1, gamma1). Production, purification, and interactions with integrins. J Biol Chem 275: 1485314859, 2000.

91. Koster J, Borradori L, and Sonnenberg A. Hemidesmosomes: molecular organisation and their importance for cell adhesion and disease. Heidelberg: Springer Verlag, 2004.

92. Kostka G, Giltay R, Bloch W, Addicks K, Timpl R, Fässler R, and Chu ML. Perinatal lethality and endothelial cell abnormalities in several vessel compartments of fibulin-1deficient mice. Mol Cell Biol 21: 7025-7034, 2001.

93. Lane TF and Sage EH. The biology of SPARC, a protein that modulates cell-matrix interactions. FASEB J 8: 163-173, 1994.

94. Lawler J. The functions of thrombospondin-1 and-2. Curr Opin Cell Biol 12: 634-640, 2000.

95. Lawler J. Thrombospondin-1 as an endogenous inhibitor of angiogenesis and tumor growth. J Cell Mol Med 6: 1-12, 2002.

96. Lawson ND, Scheer N, Pham VN, Kim CH, Chitnis AB, Campos-Ortega JA, and Weinstein BM. Notch signaling is required for arterial-venous differentiation during embryonic vascular development. Development 128: 3675-3683, 2001. 
97. LeCouter J, Kowalski J, Foster J, Hass P, Zhang Z, Dillard-Telm L, Frantz G, Rangell L, DeGuzman L, Keller GA, Peale F, Gurney A, Hillan KJ, and Ferrara N. Identification of an angiogenic mitogen selective for endocrine gland endothelium. Nature 412: 877-884, 2001.

98. Lee SP, Cunningham ML, Hines PC, Joneckis CC, Orringer EP, and Parise LV. Sickle cell adhesion to laminin: potential role for the $\alpha 5$ chain. Blood 92: 2951-2958, 1998.

99. Leung DW, Cachianes G, Kuang WJ, Goeddel DV, and Ferrara N. Vascular endothelial growth factor is a secreted angiogenic mitogen. Science 246: 1306-1309, 1989.

100.Libby RT, Champliaud M-F, Claudepierre T, Xu Y, Gibbons EP, Koch M, Burgeson RE, Hunter DD, and Brunken WJ. Laminin expression in adult and developing retinae: evidence of two novel CNS laminins. J Neurosci 20: 6517-6528, 2000.

101.Lin DC, Bullock CM, Ehlert FJ, Chen JL, Tian H, and Zhou QY. Identification and molecular characterization of two closely related $G$ protein-coupled receptors activated by prokineticins/endocrine gland vascular endothelial growth factor. J Biol Chem 277: 1927619280, 2002.

102.Lindahl P, Hellström M, Kalen M, Karlsson L, Pekny M, Pekna M, Soriano P, and Betsholtz C. Paracrine PDGF-B/PDGFR- $\beta$ signaling controls mesangial cell development in kidney glomeruli. Development 125: 3313-3322, 1998.

103.Liu Y, Wada R, Yamashita T, Mi Y, Deng CX, Hobson JP, Rosenfeldt HM, Nava VE, Chae SS, Lee MJ, Liu CH, Hla T, Spiegel S, and Proia RL. Edg-1, the G protein-coupled receptor for sphingosine-1-phosphate, is essential for vascular maturation. J Clin Invest 106: 951-961, 2000.

104.Loughna S and Sato TN. Angiopoietin and Tie signaling pathways in vascular development. Matrix Biol 20: 319-325, 2001.

105.Maisonpierre PC, Suri C, Jones PF, Bartunkova S, Wiegand SJ, Radziejewski C, Compton D, McClain J, Aldrich TH, Papadopoulos N, Daly TJ, Davis S, Sato TN, and Yancopoulos GD. Angiopoietin-2, a natural antagonist for Tie2 that disrupts in vivo angiogenesis. Science 277: 55-60, 1997.

106.Masuda Y, Takatsu Y, Terao Y, Kumano S, Ishibashi Y, Suenaga M, Abe M, Fukusumi S, Watanabe T, Shintani Y, Yamada T, Hinuma S, Inatomi N, Ohtaki T, Onda H, and Fujino M. Isolation and identification of EG-VEGF/prokineticins as cognate ligands for two orphan G-protein-coupled receptors. Biochem Biophys Res Commun 293: 396-402, 2002.

107.Meier T and Ruegg MA. The Role of Dystroglycan and Its Ligands in Physiology and Disease. News Physiol Sci 15: 255-259, 2000.

108.Mertens G, Cassiman JJ, Van den Berghe H, Vermylen J, and David G. Cell surface heparan sulfate proteoglycans from human vascular endothelial cells. Core protein characterization and antithrombin III binding properties. J Biol Chem 267: 20435-20443, 1992.

109.Miner JH, Cunningham J, and Sanes JR. Roles for laminin in embryogenesis: exencephaly, syndactyly, and placentopathy in mice lacking the laminin $\alpha 5$ chain. J Cell Biol 143: 1713-1723, 1998.

110.Miner JH, Lewis RM, and Sanes JR. Molecular cloning of a novel laminin chain, $\alpha 5$, and widespread expression in adult mouse tissues. J Biol Chem 270: 28523-28526, 1995.

111. Miner JH and Li C. Defective glomerulogenesis in the absence of laminin $\alpha 5$ demonstrates a developmental role for the kidney glomerular basement membrane. Dev Biol 217: 278-289, 2000. 
112.Miner JH and Yurchenco PD. Laminin functions in tissue morphogenesis. Ann Rev Cell Dev Biol 20: 255-282, 2004.

113.Miosge N, Sasaki T, and Timpl R. Evidence of nidogen-2 compensation for nidogen-1 deficiency in transgenic mice. Matrix Biol 21: 611-621, 2002.

114. Miyagoe Y, Hanaoka K, Nonaka I, Hayasaka M, Nabeshima Y, Arahata K, Nabeshima Y, and Takeda S. Laminin $\alpha 2$ chain-null mutant mice by targeted disruption of the LamA2 gene: a new model of merosin (laminin-2)-deficient congenital muscular dystrophy. FEBS Letters 415: 33-39, 1997.

115.Miyagoe-Suzuki Y, Nakagawa M, and Takeda S. Merosin and congenital muscular dystrophy. Microsc Res Tech 48: 181-191, 2000.

116. Miyamoto S, Katz BZ, Lafrenie RM, and Yamada KM. Fibronectin and integrins in cell adhesion, signaling, and morphogenesis. Ann N Y Acad Sci 857: 119-129, 1998.

117. Moulson CL, Li C, and Miner JH. Localization of Lutheran, a novel laminin receptor, in normal, knockout, and transgenic mice suggests an interaction with laminin $\alpha 5$ in vivo. Dev Dyn 222: 101-114, 2001.

118.Murshed M, Smyth N, Miosge N, Karolat J, Krieg T, Paulsson M, and R. N. The absence of nidogen 1 does not affect murine basement membrane formation. Mol Cell Biol 20: 7007-7012., 2000.

119.Nagy JA, Vasile E, Feng D, Sundberg C, Brown LF, Manseau EJ, Dvorak AM, and Dvorak HF. VEGF-A induces angiogenesis, arteriogenesis, lymphangiogenesis, and vascular malformations. Cold Spring Harb Symp Quant Biol 67: 227-237, 2002.

120.Neufeld G, Cohen T, Shraga N, Lange T, Kessler O, and Herzog Y. The neuropilins: multifunctional semaphorin and VEGF receptors that modulate axon guidance and angiogenesis. Trends Cardiovasc Med 12: 13-19, 2002.

121.Nievers MG, Schaapveld RQ, and Sonnenberg A. Biology and function of hemidesmosomes. Matrix Biol 18: 5-17, 1999.

122.Norose K, Clark JI, Syed NA, Basu A, Heber-Katz E, Sage EH, and Howe CC. SPARC deficiency leads to early-onset cataractogenesis. Invest Ophthalmol Vis Sci 39: 2674-2680, 1998.

123.O'Reilly MS, Boehm T, Shing Y, Fukai N, Vasios G, Lane WS, Flynn E, Birkhead JR, Olsen BR, and Folkman J. Endostatin: an endogenous inhibitor of angiognesis and tumor growth. Cell 88: 277-285, 1997.

124. Orlando RA and Cheresh DA. Arginine-glycine-aspartic acid binding leading to molecular stabilization between integrin $\alpha v \beta 3$ and its ligand. J Biol Chem 266: 19543-19550, 1991.

125.Panayotou G, End P, Aumailley M, Timpl R, and Engel J. Domains of laminin with growth-factor activity. Cell 56: 93-101, 1989.

126.Pardanaud $\mathbf{L}$ and Dieterlen-Lievre F. Manipulation of the angiopoietic/ hemangiopoietic commitment in the avian embryo. Development 126: 617-627, 1999.

127.Parsons SF, Lee G, Spring FA, Willig TN, Peters LL, Gimm JA, Tanner MJ, Mohandas N, Anstee DJ, and Chasis JA. Lutheran blood group glycoprotein and its newly characterized mouse homologue specifically bind $\alpha 5$ chain-containing human laminin with high affinity. Blood 97: 312-320, 2001.

128.Parsons SF, Mallinson G, Holmes CH, Houlihan JM, Simpson KL, Mawby WJ, Spurr NK, Warne D, Barclay AN, and Anstee DJ. The Lutheran blood group glycoprotein, another member of the immunoglobulin superfamily, is widely expressed in human tissues 
and is developmentally regulated in human liver. Proc Natl Acad Sci USA 92: 5496-5500, 1995.

129.Paulsson M, Aumailley M, Deutzmann R, Timpl R, Beck K, and Engel J. Lamininnidogen complex: extraction with chelating agents and structural characterization. Eur $J$ Biochem 166: 11-19, 1987.

130.Pece N, Vera S, Cymerman U, White RI, Jr., Wrana JL, and Letarte M. Mutant endoglin in hereditary hemorrhagic telangiectasia type 1 is transiently expressed intracellularly and is not a dominant negative. J Clin Invest 100: 2568-2579, 1997.

131.Pedraza C, Geberhiwot T, Ingerpuu S, Assefa D, Wondimu Z, Kortesmaa J, Tryggvason K, Virtanen I, and Patarroyo M. Monocytic cells synthesize, adhere to, and migrate on laminin 8. J Immunol 165: 5831-5838, 2000.

132.Pepper MS. Transforming growth factor-beta: vasculogenesis, angiogenesis, and vessel wall integrity. Cytokine Growth Factor Rev 8: 21-43, 1997.

133.Pihlajaniemi T and Rehn M. Two new collagen subgroups: membrane-associated collagens and types XV and XVII. Prog Nucleic Acid Res Mol Biol 50: 225-262, 1995.

134.Ponce ML, Hibino S, Lebioda AM, Mochizuki M, Nomizu M, and Kleinman HK. Identification of a potent peptide antagonist to an active laminin-1 sequence that blocks angiogenesis and tumor growth. Cancer Res 63: 5060-5064, 2003.

135.Ponce ML, Nomizu M, Delgado MC, Kuratomi Y, Hoffman MP, Powell S, Yamada Y, Kleinman HK, and Malinda KM. Identification of endothelial cell binding sites on the laminin gamma 1 chain. Circ Res 84: 688-694, 1999.

136.Pöschl E, Fox JW, Block D, Mayer U, and Timpl R. Two non-contiguous regions contribute to nidogen binding to a single EGF-like motif of the laminin $\gamma 1$ chain. EMBO J 13: 3741-3747, 1994.

137.Pöschl E, Schlotzer-Schrehardt U, Brachvogel B, Saito K, Ninomiya Y, and Mayer U. Collagen IV is essential for basement membrane stability but dispensable for initiation of its assembly during early development. Development 131: 1619-1628, 2004.

138. Rahuel C, Colin Y, Goossens D, Gane P, El Nemer W, Cartron JP, and Le Van Kim C. Characterization of a mouse laminin receptor gene homologous to the human blood group Lutheran gene. Immunogenetics 50: 271-277, 1999.

139. Reynolds LE, Wyder L, Lively JC, Taverna D, Robinson SD, Huang X, Sheppard D, Hynes RO, and Hodivala-Dilke KM. Enhanced pathological angiogenesis in mice lacking $\beta 3$ integrin or $\beta 3$ and $\beta 5$ integrins. Nat Med 8: 27-34, 2002.

140.Risau W. Differentiation of endothelium. FASEB J 9: 926-933, 1995.

141.Risau W. Mechanisms of angiogenesis. Nature 386: 671-674, 1997.

142.Roberts WG and Palade GE. Endothelial cell fenestrae and fenestral diaphragms. In: Morphogenesis of Endothelium, edited by Rubanyi GM and Risau W. Amsterdam: Hartwood Publishers, 2000, p. 23-41.

143.Rodriguez-Manzaneque JC, Lane TF, Ortega MA, Hynes RO, Lawler J, and IruelaArispe ML. Thrombospondin-1 suppresses spontaneous tumor growth and inhibits activation of matrix metalloproteinase-9 and mobilization of vascular endothelial growth factor. Proc Natl Acad Sci USA 98: 12485-12490, 2001.

144.Rossant $\mathbf{J}$ and Howard L. Signaling pathways in vascular development. Annu Rev Cell Dev Biol 18: 541-573, 2002.

145.Ruhrberg C. Growing and shaping the vascular tree: multiple roles for VEGF. Bioessays 25: 1052-1060, 2003. 
146.Ruhrberg C, Gerhardt H, Golding M, Watson R, Ioannidou S, Fujisawa H, Betsholtz C, and Shima DT. Spatially restricted patterning cues provided by heparin-binding VEGF-A control blood vessel branching morphogenesis. Genes Dev 16: 2684-2698, 2002.

147.Ryan MC, Lee K, Miyashita Y, and Carter WG. Targeted disruption of the LAMA3 gene in mice reveals abnormalities in survival and late stage differentiation of epithelial cells. $J$ Cell Biol 145: 1309-1323, 1999.

148. Saoncella S, Echtermeyer F, Denhez F, Nowlen JK, Mosher DF, Robinson SD, Hynes RO, and Goetinck PF. Syndecan-4 signals cooperatively with integrins in a Rho-dependent manner in the assembly of focal adhesions and actin stress fibers. Proc Natl Acad Sci USA 96: 2805-2810, 1999.

149.Sasaki T, Fässler R, and Hohenester E. Laminin: the crux of basement membrane assembly. J Cell Biol 164: 959-963, 2004.

150.Sasaki T, Hohenester E, and Timpl R. Structure and function of collagen-derived endostatin inhibitors of angiogenesis. IUBMB Life 53: 77-84, 2002.

151.Sasaki T, Larsson H, Tisi D, Claesson-Welsh L, Hohenester E, and Timpl R. Endostatins derived from collagens XV and XVIII differ in structural and binding properties, tissue distribution and anti-angiogenic activity. J Mol Biol 301: 1179-1190, 2000.

152.Sasaki T, Mann K, Murphy G, Chu M-L, and Timpl R. Different susceptibilities of fibulin-1 and fibulin-2 to cleavage by matrix metalloproteinase and other tissue proteases. Eur J Biochem 240: 427-434, 1996.

153.Sasaki T and Timpl R. Domain IVa of laminin alpha5 chain is cell-adhesive and binds beta1 and alphaVbeta3 integrins through Arg-Gly-Asp. FEBS Lett 509: 181-185, 2001.

154.Schymeinsky J, Nedbal S, Miosge N, Poschl E, Rao C, Beier DR, Skarnes WC, Timpl R, and Bader BL. Gene structure and functional analysis of the mouse nidogen-2 gene: nidogen-2 is not essential for basement membrane formation in mice. Mol Cell Biol 22: 6820-6830, 2002.

155.Senger DR, Asch BB, Smith BD, Perruzzi CA, and Dvorak HF. A secreted phosphoprotein marker for neoplastic transformation of both epithelial and fibroblastic cells. Nature 302: 714-715, 1983.

156.Shimizu H, Hosokawa H, Ninomiya H, Miner JH, and Masaki T. Adhesion of cultured bovine aortic endothelial cells to laminin-1 mediated by dystroglycan. J Biol Chem 274: 11995-12000, 1999.

157.Shuttleworth CA. Type VIII Collagen. Int J Biochem Cell Biol 29: 1145-1148, 1997.

158.Shyy JY and Chien S. Role of integrins in endothelial mechanosensing of shear stress. Circ Res 91: 769-775, 2002.

159.Sixt M, Engelhardt B, Pausch F, Hallmann R, Wendler O, and Sorokin LM. Endothelial cell laminin isoforms, laminin 8 and 10, play decisive roles in in T-cell recruitment across the blood-brain-barrier in an experimental autoimmune encephalitis model (EAE). J Cell Biol 153: 933-945, 2001.

160.Sonnenberg A, Linders C, Deems JA, and Kennel SJ. The $\alpha 6 \beta 1$ (VLA-6) and $\alpha 6 \beta 4$ protein complexes: tissue distribution and biochemical properties. J Cell Sci 96: 207-217, 1990.

161.Sorokin LM, Frieser M, Pausch F, Kröger S, Ohage E, and Deutzmann R. Developmental regulation of laminin $\alpha 5$ suggests a role in epithelial and endothelial cell maturation. Dev Biol 189: 285-300, 1997. 
162.Sorokin LM, Girg W, Gopfert T, Hallmann R, and Deutzmann R. Expression of novel $400 \mathrm{kD}$ laminin chains by mouse and bovine endothelial cells. Eur J Biochem 223: 603-610, 1994.

163.Sorokin LM, Pausch F, Durbeej M, and Ekblom P. Differential expression of five laminin $\alpha(1-5)$ chains in developing and adult mouse kidney. Dev Dyn 210: 446-462, 1997.

164.Sowemimo-Coker SO, Meiselman HJ, and Francis RB, Jr. Increased circulating endothelial cells in sickle cell crisis. Am J Hematol 31: 263-265, 1989.

165.Stan R-V, Kubitza M, and Palade GE. PV-1 is a component of the fenestral and stomatal diaphragms in fenestrated endothelia. Proc Natl Acad Sci USA 96: 13203-13207, 1999.

166.Stewart PA and Wiley MJ. Developing nervous tissue induces formation of blood-brain barrier characteristics in invading endothelial cells: a study using quail-chick transplantation chimeras. Dev Biol 84: 183-192, 1981.

167.Suri C, McClain J, Thurston G, McDonald DM, Zhou H, Oldmixon EH, Sato TN, and Yancopoulos GD. Increased vascularization in mice overexpressing angiopoietin-1. Science 282: 468-471, 1998.

168.Talts JF, Andac Z, Göhring W, Brancaccio A, and Timpl R. Binding of G domains of laminin $\alpha 1$ and $\alpha 2$ chains and perlecan to heparin, sulfatides, $\alpha$-dystroglycan and several extracellular matrix proteins. EMBO J 18: 863-870, 1999.

169.Talts JF, Mann K, Yamada Y, and Timpl R. Structural analysis and proteolytic processing of recombinant $G$ domain of mouse laminin $\alpha 2$ chain. FEBS Lett 426: 71-76, 1998.

170.Talts JF, Sasaki T, Miosge N, Gohring W, Mann K, Mayne R, and Timpl R. Structural and functional analysis of the recombinant $G$ domain of the laminin $\alpha 4$ chain and its proteolytic processing in tissues. J Biol Chem 275: 35192-35199, 2000.

171. Taverna D and Hynes RO. Reduced blood vessel formation and tumor growth in $\alpha 5$ integrin- negative teratocarcinomas and embryoid bodies. Cancer Res 61: 5255-5261, 2001.

172.Taverna D, Moher H, Crowley D, Borsig L, Varki A, and Hynes RO. Increased primary tumor growth in mice null for $\beta 3$ - or $\beta 3 / \beta 5$-integrins or selectins. Proc Natl Acad Sci USA 101: 763-768, 2004.

173.Thurston G, Rudge JS, Ioffe E, Zhou H, Ross L, Croll SD, Glazer N, Holash J, McDonald DM, and Yancopoulos GD. Angiopoietin-1 protects the adult vasculature against plasma leakage. Nat Med 6: 460-463, 2000.

174.Thyboll J, Kortesmaa J, Cao R, Soininen R, Wang L, Iivanainen A, Sorokin L, Risling M, Cao Y, and Tryggvason K. Deletion of the laminin $\alpha 4$ chain leads to impaired microvessel maturation. Mol Cell Biol 22: 1194-1202, 2002.

175.Timpl R. Macromolecular assembly of basement membranes. Curr Opin Cell Biol 8: 618624, 1996.

176.Timpl R. Structure and biological activity of basement membrane proteins. Eur J Biochem 180: 487-502, 1989.

177.Timpl R and Brown J. The laminins. Matrix Biology 14: 275-281, 1994.

178.Timpl R and Brown JC. Supramolecular assembly of basement membranes. Bioessays 18: 123-132, 1996.

179.Timpl R, Rohde H, Gehron-Robey P, Rennard SI, Foidart JM, and Martin G. Laminina glycoprotein from basement membranes,. J Biol Chem 254: 9933-9937, 1979.

180.Timpl R, Sasaki T, Kostka G, and Chu ML. Fibulins: a versatile family of extracellular matrix proteins. Nat Rev Mol Cell Biol 4: 479-489, 2003. 
181.Timpl R, Tisi D, Talts JF, Andac Z, Sasaki T, and Hohenester E. Structure and function of laminin LG modules. Matrix Biol 19: 309-317, 2000.

182.Tisi D, Talts JF, Timpl R, and Hohenester E. Structure of the C-terminal laminin G-like domain pair of the laminin $\alpha 2$ chain harbouring binding sites for $\alpha$-dystroglycan and heparin. EMBO J 19: 1432-1440, 2000.

183.Tokida Y, Aratani Y, Morita A, and Kitagawa Y. Production of two variant laminin forms by endothelial cells and shift of their relative levels by angiostatic steroids. J Biol Chem 265: 18123-18129, 1990.

184.Tomono Y, Naito I, Ando K, Yonezawa T, Sado Y, Hirakawa S, Arata J, Okigaki T, and Ninomiya $\mathbf{Y}$. Epitope-defined monoclonal antibodies against multiplexin collagens demonstrate that type XV and XVIII collagens are expressed in specialized basement membranes. Cell Struct Funct 27: 9-20, 2002.

185.Tran EH, Hoekstra K, Rooijen Nv, Dijkstra CD, and Owens T. Immune evasion of the central nervous system parenchyma and experimental allergic encephalomyelitis, but not leukocyte extravasation from blood, are prevented in macrophage-depleted mice. J Immunol 161: 3767-3775, 1998.

186.Tunggal P, Smyth N, Paulsson M, and Ott M-C. Laminins: structure and genetic regulation. Micro Res Tech 51: 214-227, 2000.

187.Udani M, Zen Q, Cottman M, Leonard N, Jefferson S, Daymont C, Truskey G, and Telen MJ. Basal cell adhesion molecule/lutheran protein. The receptor critical for sickle cell adhesion to laminin. J Clin Invest 101: 2550-2558, 1998.

188.Uitto J. Heritable connective tissue disorders. Adv Exp Med Biol 455: 15-21, 1999. 
189.Valenzuela DM, Griffiths JA, Rojas J, Aldrich TH, Jones PF, Zhou H, McClain J, Copeland NG, Gilbert DJ, Jenkins NA, Huang T, Papadopoulos N, Maisonpierre PC, Davis S, and Yancopoulos GD. Angiopoietins 3 and 4: diverging gene counterparts in mice and humans. Proc Natl Acad Sci USA 96: 1904-1909, 1999.

190.van der Flier A and Sonnenberg A. Function and interactions of integrins. Cell Tissue Res 305: 285-298, 2001.

191.Vidal F, Baudoin C, Miquel C, Galliano MF, Christiano AM, Uitto J, Ortonne JP, and Meneguzzi G. Cloning of the laminin $\alpha 3$ chain gene (LAMA3) and identification of a homozygous deletion in a patient with Herlitz junctional epidermolysis bullosa. Genomics 30: 273-280, 1995.

192.Wang HU and Anderson DJ. Eph family transmembrane ligands can mediate repulsive guidance of trunk neural crest migration and motor axon outgrowth. Neuron 18: 383-396, 1997.

193.Wang HU, Chen ZF, and Anderson DJ. Molecular distinction and angiogenic interaction between embryonic arteries and veins revealed by ephrin-B2 and its receptor Eph-B4. Cell 93: 741-753, 1998.

194.Wang S, Wu Z, Sorenson CM, Lawler J, and Sheibani N. Thrombospondin-1-deficient mice exhibit increased vascular density during retinal vascular development and are less sensitive to hyperoxia-mediated vessel obliteration. Dev Dyn 228: 630-642, 2003.

195.Wilting J, Christ B, Yuan L, and Eichmann A. Cellular and molecular mechanisms of embryonic haemangiogenesis and lymphangiogenesis. Naturwissenschaften 90: 433-448, 2003.

196. Wolburg H and Risau W. Formation of the blood-brain barrier. In: Neuroglia, edited by Kettenmann H, Ransom, B. R. Oxford: Oxford University Press, 1995, p. 763-776.

197.Wondimu Z, Geberhiwot T, Ingerpuu S, Juronen E, Xie X, Lindbom L, Doi M, Kortesmaa J, Thyboll J, Tryggvason K, Fadeel B, and Patarroyo M. An endothelial laminin isoform, laminin $8(\alpha 4 \beta 1 \gamma 1)$, is secreted by blood neutrophils, promotes neutrophil migration and extravasation, and protects neutrophils from apoptosis. Blood 104: 1859-1866, 2004.

198.Xu H, Wu XR, Wewer UM, and Engvall E. Murine muscular dystrophy caused by a mutation in the laminin $\alpha 2$ (Lama2) gene. Nat Genet 8: 297-302, 1994.

199.Yan Q and Sage EH. SPARC, a matricellular glycoprotein with important biological functions. J Histochem Cytochem 47: 1495-1506, 1999.

200.Yancopoulos GD, Davis S, Gale NW, Rudge JS, Wiegand SJ, and Holash J. Vascularspecific growth factors and blood vessel formation. Nature 407: 242-248, 2000.

201.Yang JT, Rayburn H, and Hynes RO. Embryonic mesodermal defects in $\alpha 5$ integrindeficient mice. Development 119: 1093-1105, 1993.

202. Ylikarppa R, Eklund L, Sormunen R, Muona A, Fukai N, Olsen BR, and Pihlajaniemi T. Double knockout mice reveal a lack of major functional compensation between collagens XV and XVIII. Matrix Biol 22: 443-448, 2003.

203.Yu H and Talts JF. Beta1 integrin and alpha-dystroglycan binding sites are localized to different laminin-G-domain-like (LG) modules within the laminin $\alpha 5$ chain $G$ domain. Biochem J 371: 289-299, 2003.

204. Yurchenco P and Cheng YS. Self-assembly and calcium-binding sites in laminin. $J$ Biol Chem 268: 17286-17299, 1993. 
205.Yurchenco P, Quan Y, Colognato H, Mathus T, Harrison D, Yamada Y, and O'Rear JJ. The $\alpha$ chain of laminin- 1 is independently secreted and drives secretion of its $\beta$ and $\gamma$ chain partners. Proc Natl Acad Sci USA 94: 10189-10194, 1997.

206. Yurchenco PD, Cheng YS, and Colognato H. Laminin forms an independent network in basement membranes. J Cell Biol 117: 1119-1133, 1992.

207.Zhang ET, Inman CBE, and Weller RO. Interrelationships of the pia mater and the perivascular (Virchow-Robin) spaces in the human cerebrum. J Anat 170: 111-123, 1990.

208.Zhou Z, Doi M, Wang J, Cao R, Liu B, Chan KM, Kortesmaa J, Sorokin L, Cao Y, and Tryggvason K. Deletion of laminin-8 results in increased tumor neovascularization and metastasis in mice. Cancer Res 64: 4059-4063, 2004. 


\section{Figure Legends}

Fig. 1 Schematic representation of the steps involved in endothelial cell differentiation, including endothelial cell tube formation, sprouting angiogenesis and pericyte recruitment; endothelial cell maturation into morphologically distinct capillary types; and summary of the temporal and spatial expression patterns of laminins in endothelial cell basement membranes in vivo.

Fig. 2 The major basement membrane components and their proposed interactions. Laminin and collagen type IV form independent networks that are linked by nidogens and the heparan sulphate proteoglycan, perlecan. Endothelial cell basement membranes consist principally of the laminin 8 and 10 isoforms, collagen type IV [ $\alpha 1(\mathrm{IV}) 2 \alpha 2(\mathrm{IV})]$, nidogen 1 and 2.

Fig. 3 Structure and domain description of prototype and endothelial cell laminins. The laminin 1 isoform is characterized by the presence of the laminin $\alpha 1$ chain, which combines with laminin $\beta 1$ and $\gamma 1$ chains. By contrast, endothelial cell laminins are characterized by the presence of laminin $\alpha 4$ and $\alpha 5$ chains, which combine with laminin $\beta 1$ and $\gamma 1$ chains to form laminin 8 and laminin 10, respectively. All laminin chains share structural similarities defined as domains, shown in Roman numerals. Note the N-terminal short arms composed of laminin $\alpha, \beta$ and $\gamma$ chain sequences, and the C-terminal globular $(G)$ domains composed solely of laminin $\alpha$ chain sequences. The central long arm of the all laminins is a coiled-coiled structure composed of all three chains.

Fig. 4 Differential expression of endothelial cell laminin isoforms. All endothelial cells can produce the $240 \mathrm{kDa}$ laminin $\alpha 4$ and the $400 \mathrm{kDa}$ laminin $\alpha 5$ chain. However, the use of different endothelial cell lines derived from different tissues ( bEND.3 from brain; mlEND.1 from mesenteric lymph nodes; SVEC from peripheral lymph nodes; eEND.2 from embryonic hemangiomas; sEND.1 from skin hemangiomas) (162) revealed that some endothelial cells express predominantly laminin $\alpha 4$ and others laminin $\alpha 5$, and that the expression pattern can be altered by the growth state or activation state of the cells. In general, proinflammatory cytokines induced laminin $\alpha 4$ synthesis, while angiostatic agents, like progesterone, induce laminin $\alpha 5$ synthesis. 
Fig. 5 Three major transmembrane receptor types are responsible for cell binding to laminins: the integrins (principally $\beta 1$ and $\beta 3$ integrins), $\alpha$-dystroglycan of the dystrophin-glycoprotein complex (DGC), and the Lutheran blood group glycoprotein. The DGC is connected to the cytoskeleton via dystrophin in myogenic tissues and by utrophin in all other tissues, including endothelium. Potential phorphorylation sites involved in mediating intracellular signals are marked by $(\mathrm{P})$.

Fig. 6 Potential interactions between laminins 8 and 10 and cellular receptors present on endothelial cells. Interactions with intact laminins 8 and 10 and with defined domains of the laminin $\alpha 4$ and $\alpha 5$ chains are shown. * Denotes interactions that have been demonstrated using primary endothelial cells or endothelial cell lines in vitro assays; RGD-dependent binding of murine endothelial cells to domain IVa of laminin $\alpha 5$ is unpublished data from our laboratory.

Fig. 7 Illustration of the cell layers, basement membranes and their laminin composition of CNS blood vessels with and without an inflammatory cuff. Larger blood vessels consist of an inner endothelial cell layer with basement membrane (containing laminins $\alpha 4$ and $\alpha 5$ ), bordered by the meningeal epithelium and its basement membrane (containing laminin $\alpha 1$ ), and an outer astroglial basement membrane (containing laminin $\alpha 2$ ) and astrocyte endfeet. The meningeal and astroglial basement membranes are collectively termed the parenchymal basement membranes as they delineate the border to the brain parenchyma. Only at sites of local inflammation are the endothelial and parenchymal basement membranes distinguishable and define the inner and outer limits of the perivascular space where leukocytes accumulate before infiltrating the brain parenchyma. Examination of such sites demonstrates that mononuclear infiltration occurs across endothelial basement membrane containing only the laminin $\alpha 4$ and bordered by a parenchymal basement membrane containing laminin $\alpha 1$ and $\alpha 2$. The basement membrane of microvessels where no epithelial meningeal contribution occurs appear to have a composite basement membrane containing the endothelial cell laminins, laminin $\alpha 4$ and $\alpha 5$, and laminin $\alpha 2$ produce by the astrocytes and deposited at their endfeet. Reproduced from The Journal of Cell Biology, 2001, vol. 153, pp. 933-946, by copyright permission of The Rockefeller University Press. 
PRV-00014-2004.R1 


\section{Differentiation}

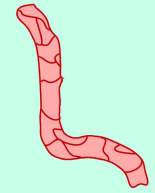

Tube Formation

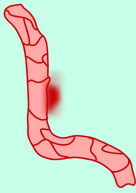

Sprouting 1 MMP activity

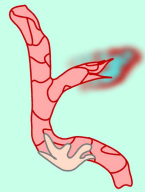

Sprouting 2 primitive matrix EC proliferation EC migration

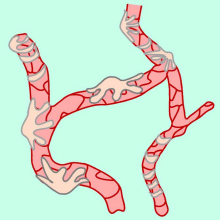

Recruitment of pericytes \& smooth muscle

\section{Laminin Expression in Endothelium}

\section{Maturation}

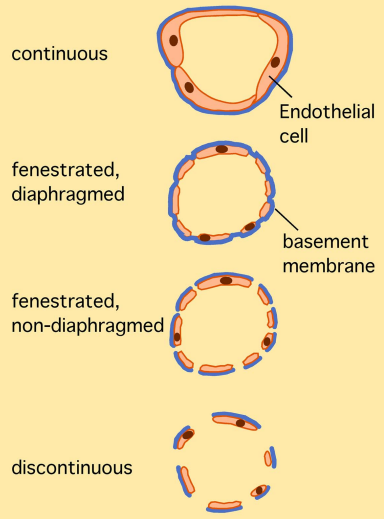

Isoform

Laminin $\alpha 4$

Laminin $\alpha 5$
Developmental Stage

E8.5 $\longrightarrow$ adult

postnatal

\section{Blood Vessel Type}

all vessels

capillaries some veins \& venules not arteries 


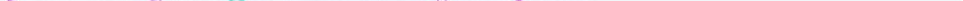




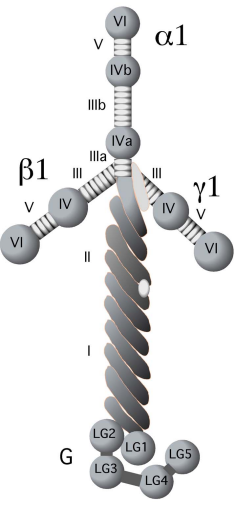

Laminin 1

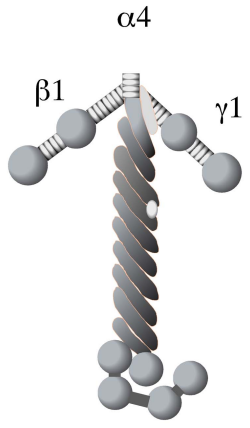

Laminin 8 $\alpha 5$

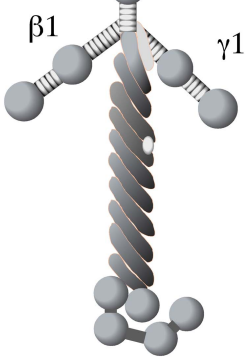

Laminin 10 
$\alpha 4$

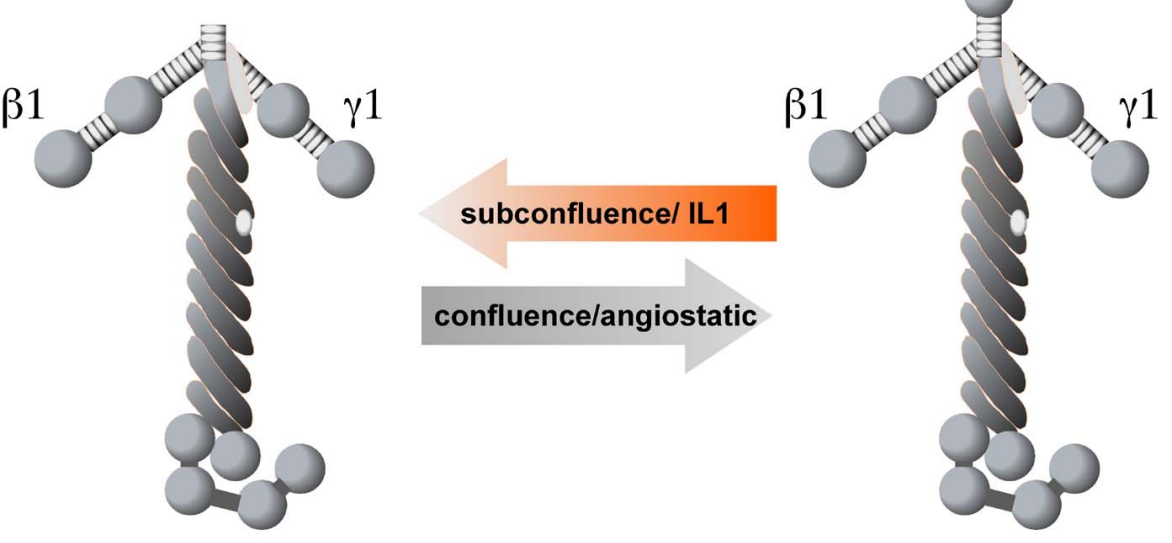

Laminin 8

Laminin 10

sEND.1, eEND.2

SVEC, mIEND.1, bEND.3 
Laminin 8

Integrin $\alpha 3 \beta 1$ probably $\alpha 4$ LG4-5

Integrin $\alpha 6 \beta 1$

Laminin $\alpha 5$

$\alpha 5$ LG1-3

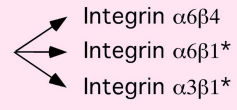

Laminin 10

$\alpha 5 \mathrm{VI}$

$\longrightarrow$ Integrin $\alpha 3 \beta 1$

$\alpha .5$ IVa (RGD)

$\alpha 5$ LG3

$\longrightarrow$ Lutheran blood group antigen*

$\alpha 5$ LG4-5

$\longrightarrow \alpha$-dystroglycan* 


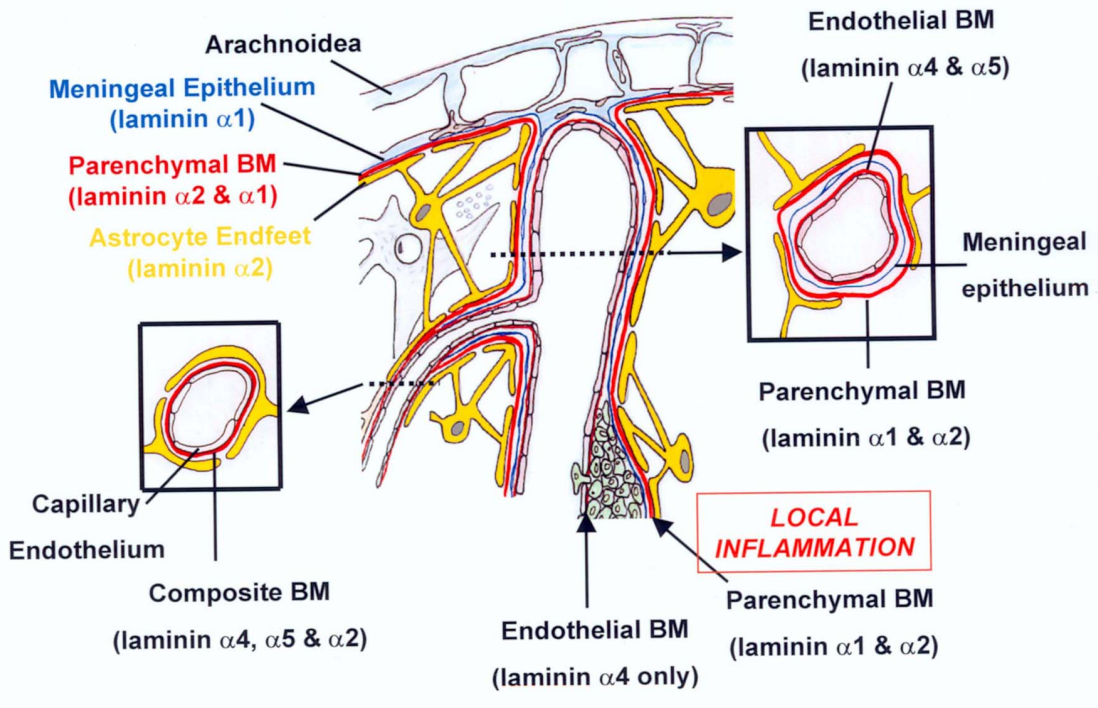

